REVISTA DE DERECHO UNED, NÚM. 8, 2011

\title{
EVOLUCIÓN HISTÓRICA DE LA DEPOSITIO IN AEDEM EN ROMA COMO PRECEDENTE DE LA CONSIGNACIÓN ACTUAL (EN TORNO A UNO DE LOS ACTOS CONSIDERADOS DE JURISDICCIÓN VOLUNTARIA) ${ }^{1}$
}

\author{
M ${ }^{\mathrm{a}}$ Lourdes Martínez de Morentin Llamas \\ Profesora de Derecho Romano \\ Universidad de Zaragoza
}

Resumen: En el presente trabajo se estudia la consignatio en algunos de los supuestos previstos en las fuentes. En primer lugar, en el caso del rechazo por parte del acreedor del cumplimiento de la obligatio que intenta llevar a cabo el deudor, por lo que se hace necesario algún medio de prueba del cumplimiento de las obligaciones, entre los que destaca, en época tardía, el documento, y la figura de los tabelliones. A continuación en caso de minoría de edad del acreedor, donde se plantea la cuestión de si se desliga de su obligación de solvere el que consigna en vez de pagar al menor o a su tutor. Por último, el supuesto de ausencia del acreedor, desconocimiento de su persona, o por defecto en la autorización al representante del acreedor, finalizando con unas primeras conclusiones donde se pretende demostrar que en todos los casos, nos hallamos dentro de la denominada jurisdicción voluntaria, denominación hallada en un frag-

${ }^{1}$ El presente trabajo forma parte de un estudio más amplio que se está llevando a cabo dentro del marco del Proyecto de Investigación, que lleva por título «La Jurisdicción voluntaria, un mandato legislativo pendiente de cumplimiento» financiado por el Ministerio de Ciencia e Innovación, DER2008-06460-CO2-01, cuyo investigador principal es el profesor doctor D. Antonio Fernández de Buján y Fernández. 
mento de Marciano contenido en el Digesto, y que ha sido estudiado en profundidad por el profesor D. Antonio Fernández de Buján.

Palabras clave: Obligatio; prueba del cumplimiento de las obligaciones; testigos; documentos de testigos: testatio; tabelliones; mora creditoris; Iurisdictio voluntaria; solutio; consignatio; tabularii; fides publica per aes et libram.

Abstract: In this piece of work the consignatio is treated in some of the foreseen cases of the sources. Firstly, in case of creditor rejection on the obligatio accomplishment that is trying to carry out the debtor, some probes for the accomplishment of the obligations are necessary, specially, the document, and the tabelliones figure. Then in case of the creditor is under age, it is questioned whether the one who orders is untied of his obligation of solvere instead of paying the creditor under age or his/her tutor. Lastly, the consignatio for the creditor absence, ignorance, or defect in the authorization of the creditor representative, and ending with the first conclusions where it is for demonstrating that all of the cases are under the entitled volunteer jurisdiction, title found in one of the Marciano fragment at Digesto, deeply studied by professor A. F. de Buján.

Key words: Obligatio; proof of performance of the obligation; oral testimony; testatio; tabelliones; mora creditoris; Iurisdictio voluntaria; solutio; consignatio; tabularii; fides publica per aes et libram.

Sumario: 1. Introducción. 2. Orígenes de la consignatio; evolución del depósito in Aedem a través de las diferentes fases del derecho romano. 3. La aparición del depósito con efectos liberatorios para el deudor. 4. Otras consideraciones sobre consignatio de la cosa debida y depósito liberatorio en las fuentes. 5. La consignatio en el supuesto de rechazo del acreedor del cumplimiento de la obligación que intenta llevar acabo el deudor. El problema de la prueba. 6. La consignatio en caso de minoría de edad del acreedor ¿se desliga de su obligación de solvere el que consigna en vez de pagar al menor o a su tutor? 7. La consignatio por ausencia del acreedor, o desconocimiento de su persona, o por defecto en la autorización al representante del acreedor, ¿libera al deudor? 8. Primeras conclusiones.

\section{INTRODUCCIÓN}

La consignación es una institución clásica del derecho civil, que ha sido regulada desde los primeros momentos en nuestro Código y 
ha permanecido inalterada hasta nuestros días. A pesar de su trascendencia práctica ha sido objeto de una insuficiente atención por nuestra doctrina; sin embargo en otros países de nuestro entorno existe una abundante regulación, como es el caso del derecho francés, alemán o italiano. Es posible considerar que su origen se remonta al Derecho romano, se conserva en nuestro derecho histórico y llega hasta la codificación. En nuestro ordenamiento es uno de los actos considerados como de jurisdicción voluntaria.

En la mayoría de las ocasiones el cumplimiento de las obligaciones no depende exclusivamente de la buena voluntad del deudor, sino que necesita de la cooperación del acreedor para que ésta pueda llevarse a cabo. En estos casos, por tanto, cuando el concurso del acreedor no se produce, el deudor se ve imposibilitado para realizar la prestación debida. Nos encontramos con un deudor que tras haber realizado todo lo que estaba en su mano para poder cumplir, sin embargo, el pago no ha podido tener lugar por una causa que recae exclusivamente en la esfera del sujeto activo de la relación obligatoria. Esto provocaría que el deudor por la sola voluntad del acreedor, quedaría obligado a él de manera indefinida, o al menos hasta que el acreedor consintiera en cooperar aceptando el pago ofrecido o, hasta que la obligación se extinguiera por otra de las causas previstas en el artículo 1156 de nuestro Código civil².

Esta situación no podía pasar desapercibida para el derecho, por lo que se articula un mecanismo que permite en estos casos, que el deudor pueda obtener su liberación con independencia de la actitud del acreedor. Este mecanismo es la consignación. Ante la negativa del acreedor de aceptar el ofrecimiento de pago, el deudor podrá recurrir a la consignación. E igualmente en aquellos supuestos en los que este ofrecimiento no se haya llevado a cabo, por resultar inútil o imposible, el deudor podrá consignar directamente.

Puesto que se trata de un mecanismo (en la terminología empleada por Cano Hurtado) $)^{3}$ de liberación extraordinario al que se faculta

\footnotetext{
${ }^{2}$ Las obligaciones se extinguen:

Por el pago o cumplimiento.

Por la pérdida de la cosa debida.

Por la condonación de la deuda.

Por la confusión de los derechos de acreedor y deudor.

Por la compensación.

Por la novación.

${ }^{3}$ Cano Hurtado, La consignación como mecanismo de liberación del deudor, Dykinson, Madrid, 2005
} 
a recurrir cuando el pago no ha podido tener lugar por los motivos aludidos, es lógico que el legislador requiera que se lleve a cabo imponiendo la adopción de cautelas y garantías para salvaguardar también los derechos del acreedor, y por ello la consignación se hará por vía judicial. El ordenamiento jurídico tutela mediante este sistema el interés del deudor en su liberación, pero esto no obsta para que se le imponga la observancia de una serie de requisitos y formalidades exigidas por la ley bajo el control judicial, de cuyo cumplimiento dependerá, en última instancia, que la consignación genere su efecto liberatorio, evitando así abusos y fraudes ${ }^{4}$.

\section{ORÍGENES DE LA CONSIGNATIO; EVOLUCIÓN DEL DEPOSITO IN AEDEM A TRAVÉS DE LAS DIFERENTES FASES DEL DERECHO ROMANO}

Hay que partir de la configuración que en derecho romano arcaico tenía la obligatio, pues de ello se evidencia la imposibilidad de que en esa época existiera alguna medida de protección del deudor cuando el incumplimiento se debiera a alguna causa a él no imputable. En esa época lo único que estaba regulado de forma extrema era el supuesto en el que el deudor no cumpliera con su prestación, generándose con ello una responsabilidad de carácter personal, de tal forma que si la prestación no se realizaba el acreedor estaba asistido de un derecho para vender al deudor como esclavo, e incluso para matarlo. La ejecución recaía sobre el cuerpo del deudor, mientras que sobre el patrimonio, sería solo indirecta, ya que el deudor, incluso sus familiares, estarían obligados a pagar para evitar de esta forma las consecuencias de la ejecución personal. Ello se pone de manifiesto con la terminología empleada en las fuentes: ligare, obligare, adstringere, obstringere, nectere, nexus, vinculum, a las que se contraponen liberatio, solutio, solvere vinculum. El ius civile arcaico imponía al deudor el cumplimiento incondicionado de la prestación al acreedor ${ }^{5}$.

Es posible, que desde antiguo en Roma, estuviera difundida la práctica del depósito de sumas de dinero, así como objetos preciosos, en los templos. Se conocía como depósito in aede (in aedem) o en ge-

\footnotetext{
23.

${ }^{5}$ Riccobono, Profilo storico della dottrina della mora nel Diritto romano, en Annali del Seminario giuridico della Università di Palermo, vol. XXIX, 1962, p. 105.
}

${ }^{4}$ Cano HuRtado, La consignación como mecanismo de liberación del deudor, cit. , p. 
neral in publico $^{6}$, costumbre que parece tuvo un origen griego ${ }^{7}$. Este uso en Roma no se discute, ya que al lado de fragmentos del Digesto, existen fuentes no jurídicas que así lo revelan. En concreto un extracto del Bachides de Plauto (2.3, pp. 306 ss.): nos apud theotimum omne aurum depos i nimus. Qui illic sacerdos es Diance Ephesiae ${ }^{8}$.

Si consideramos, por lo tanto, la posible existencia en este período, del depósito, cabría plantearse qué efectos producía. Cierta doctrina romanística antigua ${ }^{9}$, consideró que ya en esa época la realización del depósito (en lugar público) serviría para interrumpir el curso de los intereses a favor del deudor depositante, y ello apoyándose en algunos pasajes de Cicerón (ad fam., 13.56.3): Caunii praeterea debent, sed aiunt se depositam pecuniam habuisse, id velim cognoscas et, si intellexeris eos neque ex edicto neque ex decreto depositam habuisse, des operam, ut usurae Cluvio instituto tuo conserventur. El mismo autor (ad Att., 5.21.12): (...) cum ego in edicto traslaticio centensimas me observaturum haberem ... ille ex syngrapha postulabat ...; y en su misma obra (6.1.7): (...) consistere usura debuit, uae erat in edicto meo; deponere volebant: impetravi a Salaminiis, ut silerent (...).

Sin embargo, esta afirmación fue posteriormente abandonada por la mayor parte de los autores, en base a considerar que si bien Cicerón en algunos de sus escritos mencionaba el depósito, lo hacía como una solución imaginada por los gobernadores de Asia Menor para proteger a los deudores en caso de intereses convencionales; pero no puede concluirse que el depósito produjera como efectos la interrupción del curso de los intereses debidos por el deudor depositante ${ }^{10}$.

${ }^{6}$ VIDAL, Le dépôt in aede, en Revue historique de droit français et étranger, 1965, p. 35 , quien pone de manifiesto que el depósito in aede servía para dar protección tanto al dinero como a los objetos preciosos, evitando así el pillaje muy común en Roma. Esta práctica se hacía en los templos principalmente, pero cuando el vandalismo dejó de respetarlos se recurrió a los horrea, donde eran mejor guardados. En este sentido Michalon, Des lieux de dépôt d'objets précieux dans l'antiquité et de la location des coffres-forts à Rome, Paris, 1910, pp. 5-18. Si bien teniendo en cuenta que se aplica por extensión pues el término se refiere concretamente a granero, lugar donde se almacenaba el grano (ERnout ET MeILlet, Dictionnaire etymologique de la langue latine, quatrième édition, Paris, 1967).

${ }^{7}$ Vigneron, Offerre aut deponere. De l'origine de la procédure des offres réelles suivies de consignation, Liege, 1979 , pp. 19 ss.

${ }^{8}$ Según el trabajo de Herrera Bravo que analiza las comedias de Plauto, en El contrato de depósito en Derecho romano, Granada, 1987, pp. 75-84 y 445.

${ }^{9}$ Autores como Noodt, De Foenore et usuris, en Opera Omnia, t. I, lib. 3, cap. 15, Leyde, 1724, p. 258, y BRISson, De solutionibus et liberationibus, lib. 2 (De obsignatione), en Opera minora, Leyde, 1749, p. 157., cits. por CANO HuRTAdo, op. cit. p. 26.

${ }^{10}$ En este sentido Vigneron, op. cit. p. 35 ss., y Quintana OrIVE, Observaciones sobre el depósito de la cosa debida en caso de mora creditoris, en Rev. int. Dr. Ant., $3^{\mathrm{a}}$ serie, t. XLI, 1999, pp. 432-433. 
Posteriormente, en época posclásica, tanto en Roma como en Grecia el uso del depósito debió ser frecuente, en opinión de Vigneron, pero es muy probable que se hiciera con la única finalidad de poner a buen seguro el objeto de su deuda por parte del deudor; con ello se podría cumplir el objeto de la obligatio sin dificultad ante el requerimiento del acreedor y se evitarían las penosas consecuencias que su incumplimiento desencadenaba ${ }^{11}$. Sin embargo esta actuación no entrañaría ninguna consecuencia en la relación jurídica existente, por lo que no se produciría ningún efecto jurídico favorable al deudor, el cual no parece que quedara liberado de la deuda por dicho depósito.

\section{Mora creditoris}

Parece innegable la existencia de la relación de causalidad entre la aparición de la mora del acreedor y el depósito liberatorio, que se configurará posteriormente como uno de los efectos de la misma. Señala Caballero Lozano que mora y depósito son figuras que se reparten el campo de atenuación de responsabilidad del deudor, con independencia de que precisamente por el efecto liberatorio que se obtiene con el depósito, éste haya adquirido con el paso del tiempo mayor importancia ${ }^{12}$. Por ello resulta oportuno detenerse en el examen sobre el origen de la mora creditoris y otros asuntos relacionados con ella.

En general la noción de mora no pudo surgir en época arcaica debido a la situación de sometimiento personal (corporal) en que quedaba el deudor en caso de incumplimiento, respecto del acreedor ${ }^{13}$. Solamente cuando se comienza a tener una cierta indulgencia con el deudor pudo hacer su aparición esta figura ${ }^{14}$. Quizá el hito lo constituyó una Lex Poetelia Papiria de nexis (326aC) que facultó al deudor, en caso de incumplimiento de su deuda, a responder con su patrimonio y no con su cuerpo.

Pudo ser el primer siglo de nuestra era el momento en que surgieron mora debitoris y de forma paralela mora creditoris, quedan-

11. Op. cit., p. 50. Véase manus iniectio, ToRRENT, Diccionario de Derecho romano, Madrid, 2005.

${ }^{12}$ Caballero Lozano, La mora del acreedor, Barcelona, 1992, p. 43.

${ }^{13}$ Recuérdese nexum y manus iniectio.

${ }^{14}$ CuQ, Les institutions juridiques des romains, Paris, 1904, p. 569; MonTEL, La mora del debitore. Requisiti nel Diritto romano en el Diritto italiano, Padova, 1930, p. 12. 
do ambas figuras perfectamente diferenciadas como pone de relieve la terminología empleada por algunos autores para hacer referencia a cada tipo. Ello evidencia una nueva concepción de la obligatio que se constituía como un vínculo de carácter temporal, destinado a disolverse por su intrínseca naturaleza y, donde el deudor estaría destinado al cumplimiento; pero al mismo tiempo se le reconocería un derecho a su liberación, que viene garantizado con una obligación de cooperación que se impone al acreedor que provoca que si se infringe incurra en mora. Pero ¿realmente existía dicha obligación de cooperación por parte del acreedor para facilitar el cumplimiento de la obligatio debida? Esto es algo que, en nuestra opinión, no puede asegurarse, al menos en una época temprana.

$\mathrm{Al}$ examinar la mora como instituto particular nos encontramos que puede provocarla el deudor pero también el acreedor. Los requisitos de la mora del deudor (in solvendo) $\operatorname{son}^{15}$ :

$1^{\circ}$ que la obligación sea válida y tenga una acción para poder ser reclamada (por lo que no se considera existente la mora en las obligaciones naturales: nulla intelligetur mora ibi fieri ubi nulla petitio est, D. 50.17).

$2^{\circ}$ que la obligación sea exigible. Lo que no ocurre en las obligaciones condicionales o a término hasta que no se haya cumplido la condición o el término.

$3^{\circ}$ que el incumplimiento sea debido a la culpa del deudor.

$4^{\circ}$ la existencia de una obligación de pagar los intereses legales.

La mora del deudor cesa con la declaración del deudor de que va a satisfacer la prestación que comprende los intereses y su puesta efectiva a disposición del acreedor, o con la declaración del acreedor de que está preparado para recibir el pago (por lo que se extingue la obligación), pero también por un nuevo término propuesto o por la mora de la otra parte. Por el contrario, en la mora del acreedor (in accipiendo), sucede que el deudor ha hecho de manera debida su ofrecimiento de la prestación debida al acreedor, y éste la ha rechazado. El deudor no se ha liberado por tanto de su deuda, pero el objeto de la obligatio ahora pasa o corre a riesgo del acreedor, el cual puede también hacerse responsable de los daños y perjuicios por no haber aceptado en tiempo debido el ofrecimiento de pago del deudor.

${ }^{15}$ Bonfante, Istituzioni di Diritto romano, Milano, 1987, p. 350-351. 
Sin embargo, los dos tipos de mora (in accipiendo e in solvendo) no aparecen definidos en las fuentes. Los juristas romanos eran reacios a dar definiciones ${ }^{16}$, limitándose a la resolución de los casos que se sometían a su consideración ${ }^{17}$. A pesar de ello, y respecto a la mora creditoris, parece opinión dominante que ésta se verifica cuando el cumplimiento del deudor no es posible por una causa que afecta a la esfera del acreedor ${ }^{18}$. Los requisitos propios de esta figura eran de un lado que el deudor hubiera realizado una oferta regular y, de otro, una circunstancia relativa al acreedor que hiciera imposible el cumplimiento ${ }^{19}$. Cuando se habla de una circunstancia del ámbito del acreedor parece que se está configurando la mora de éste con un carácter amplio y difuso, por lo que se puede decir que se admitiría cualquier comportamiento que obstaculizara el cumplimiento del deudor, que comprendería tanto el rechazo de la prestación ofrecida, como la falta de cooperación del acreedor, destinatario de la prestación, en el perfeccionamiento del vínculo obligatorio y en su ejecución; y se extendería en general a cualquier caso en que la prestación no pudo ser realizada, porque el acreedor estuviera ausente o de otro modo impedido. La razón de esta rigurosa concepción, en palabras de Cano Hurtado, radicaría en la ausencia de institutos y de remedios idóneos que garantizasen al acreedor sin dañar al deudor, impregnado todo a su vez, de una fuerte necesidad de proteger al deudor (favor debitoris). Parece muy probable que en esta época todavía se desconociese la posibilidad de consignar con efecto liberatorio para el deudor. En su lugar, se acoge como principal efecto de la

${ }^{16}$ In iure civile omnis definitio periculosa est.; parum est enim, ut non subverti possit (Iavoleno lib. 10 Epistolarum, D. 50,17,202). Según Cicerón, De orat., 2, 25, la definición es un juego escolástico peligroso en la práctica.

${ }^{17}$ Sobre la labor llevada a cabo por los juristas, véase en general: los tres estudios de La PIRA sobre La genesi del sistema nella giurisprudenza romana, en Studi Virgilii, 1935, pp. 159 ss., BIDR, I, 1934, pp. 336 ss, y SDHI, 1, 1935, pp. 319 ss..; ScHulZ, History of roman legal science, 1946; ÁlVAREZ SÁREZ, La jurisprudencia romana en la hora presente, Madrid, 1966, pp. 131 ss; ARANGio RuIZ, Historia del Derecho romano, traducción española de F. de Pelsmaeker, $4^{\mathrm{a}}$ ed., Madrid, 1980, pp. 153-163; BRETONE, Tecniche e ideologie dei giuristi romani, $2^{\mathrm{a}}$ ed., 1982. reimpr. 1985; GARCÍA GARRIDO, La jurisprudencia romana y la elaboración casuística del derecho, en Derecho privado romano II, Casos y decisiones jurisprudenciales, $3^{\text {a }}$ ed. Dykinson, Madrid, 1985, pp. 3-62 y ahora en Derecho Privado Romano, Casos, Acciones, Instituciones, Dykinson, Madrid, 1999, pp. 83-129; CHuRRUCA (con R. MENTXACA), Introducción histórica al Derecho romano, $7^{\mathrm{a}}$ ed., Bilbao, 1994, pp. 153 ss.

${ }^{18}$ Montel, voz Mora (Diritto romano), en NDI, vol. VIII, Torino, 1939, Bonfante, Istituzioni, cit., p. 350. GARCía GARRIDO, voz Mora creditoris en Diccionario de Jurisprudencia romana, $3^{\circ}$ ed., Madrid, 1990

${ }^{19}$ Vigneron, op. cit., p. 53. 
mora creditoris, la posibilidad de que el deudor abandonara el objeto debido para obtener así su liberación ${ }^{20}$.

Esta medida excesiva, gradualmente evolucionó hasta su supresión como medio de liberación del deudor, en época justinianea. Y solo encontraría su razón de ser si la ubicamos en el momento histórico en que fue aplicada, pues ante el desconocimiento de la consignación, se revelaba como la única alternativa con la que contaba el deudor, ya que mediante ella se conseguía la liberación del deudor ${ }^{21}$.

Esta facultad del deudor de liberarse del vínculo obligatorio con el abandono del objeto debido, aparece en el siguiente texto de Ulpiano:

D.18.6.1.4 (Ulpianus lib. 38 ad Sabinum): Si doliare vinum emeris nec de trayendo eo quicquam convenerit, id Viteri actum, ut ante evacuarentur quam ad vindimiam opera forum futura sit necesaria: quod si non sint evacuata, faciendum, quod veteres putaverunt, per corvent venditorem mensuram facere et effundere: veteres enim hoc propter mensuram suaserunt, si, quanta mensura esset, non appareat, videlicet ut appareret, quantum emptori perierit. Que resume la doctrina de los veteres sobre el asunto consultado:

Si hubieses comprado vino en tinajas y nada se conviniese acerca de la entrega del mismo, se considerará convenido que han de dejar libres las tinajas antes de que sean necesarias para la vendimia; porque si no se dejan vacías, habrá de acudirse como opinaron los antiguos, a que el vendedor haga una medición por cestas y vierta el vino. Los antiguos aconsejaron lo de la medición si no estaba claro cuanta fuese la cantidad, al objeto de que se mostrase cuánto se había perdido para el comprador ${ }^{22}$.

Por tanto cuando no se pactaba precisamente un plazo para la entrega del vino, ésta había de realizarse como máximo antes de la época de la siguiente vendimia, que tenía lugar en el mes de septiembre. Si el comprador no la verificaba, el vendedor podría verse liberado de su obligación de entrega, pudiendo disponer del vino, hasta el extremo de poder derramarlo, previa operación de medida del líquido, lo que no eximiría al comprador de pagar su precio ${ }^{23}$.

${ }^{20}$ CIRIER, De la demeure du créancier en Droit Romain, Paris, 1886, p 86 ss.; CRISTÓBAL Montes, Curso de Derecho romano (Derecho de obligaciones), Caracas, 1964, p. 128.

${ }^{21}$ Cano Hurtado, La consignación como mecanismo, cit., p. 28.

${ }^{22}$ Traducción recogida por BENítezLóPEZ, La venta de vino y otras mercancías en la jurisprudencia romana, Madrid, 1994, p. 110, y cit. por CANO HURTADO, op. cit., p. 29.

${ }^{23}$ Aunque matiza el autor mencionado que la necesidad de medir el vino por parte del vendedor antes de deshacerse de él, sólo estaría justificada en las ventas a granel, pues en aquellas con envase incluido en el precio no sería lógico ni económico conducirse de tal modo, ya que las vasijas no serían precisas al vendedor para su actividad comercial, y además la cantidad estaría determinada desde el primer momento necesariamente (BENíTEzLóPEZ, op. cit., p. 151). 
Parece ser que el vino debió de constituir el producto más relevante de la economía romana, tras la reforma agraria producida por las guerras púnicas, por lo que parece estar justificada la doctrina de los juristas antiguos, que desconocieron el remedio de la consignación ${ }^{24}$. Por lo tanto, no se podría obligar al vendedor con una nueva carga que supondría tener que conservar en su propia tinaja el vino que no hubiese sido retirado por el comprador, lo cual le impediría utilizarlo nuevamente en la próxima vendimia (obligándole a adquirir otra nueva).

Catón el Censor en su Tratado De Agricultura en el capítulo 147 que establece normas sobre la venta de la uva pendiente y vino ya elaborado, parece recoger la misma idea, ya expuesta, que resume el parecer de los antiguos: Hac lege vinum pendens venire oportet: vinaceos inlutos et facem relinquito. Locus vinis ad Kalendas Octobres Primas dabitur, si non ante ea exportaverit, dominus vino quid volet faciet. Cetera lex, quae oleae pendenti (si la uva en la cepa debe venderse, se haga en estas condiciones: deben dejarse los posos sin lavar y la hez; se depositará el vino hasta las próximas calendas de octubre; si el comprador no lo ha transportado antes, que haga el dueño lo que quiera. Para las demás cosas, las mismas condiciones que para las olivas pendientes).

Por lo tanto se pone de manifiesto cómo el vendedor podría hacer lo que tuviera por conveniente, incluyéndose por tanto, también su abandono cuando el comprador transcurrido el tiempo máximo previsto para su retirada, no lo hiciera.

El capítulo 148 recoge un compendio de normas relativas a la venta de vino en vasijas, donde se prevé las consecuencias del retraso o incumplimiento por cualquiera de los contratantes en relación con la degustatio, la medida y el transporte, que constituían típicas manifestaciones de la obligación de cooperación del acreedor, cuya violación daría lugar a la mora creditoris. Parece ser, en palabras de Riccobono, que sería ante esa situación y ante la injusticia que supondría para el deudor permanecer indefinidamente vinculado por la conducta voluntaria o no del acreedor, y ante el desconocimiento de la consignación, por lo que se le facultaría para abandonar el objeto debido ${ }^{25}$.

\footnotetext{
${ }^{24}$ En opinión de Riccobono, op. cit., p 126, aunque los veteres recogieron ese principio en relación a una compraventa de vino, es posible considerar tal opinión aplicable a otras hipótesis de obligaciones.

${ }^{25}$ Riccobono jr., op. cit., p. 139.
} 
Siguiendo con el mismo ejemplo, si el comprador incurriera en mora en la recepción del vino, el vendedor estaría facultado para medirlo. Esta operación tendría como finalidad comprobar la cantidad de vino contenido en las vasijas, así como para separar aquella parte sobre la que se hubiera realizado la emptio-venditio. El vino podría permanecer en depósito en poder del vendedor hasta el 1 de octubre, fecha en la que una vez realizada la vendimia y las tareas de elaboración del mosto, las botas ocupadas serían imprescindibles para ser llenadas de nuevo y comenzar la crianza hasta el año siguiente. O sea que a partir de primeros de octubre el vendedor se encontraría facultado, mediando mora en el comprador, para disponer del vino a su arbitrio (pudiendo llegar, en último extremo, a su derramamiento) $)^{26}$.

Por todo ello podría decirse, que en la época Republicana, sería posible situar el origen el instituto de la mora, y en concreto, la mora creditoris. Sin embargo en esta época, se carecería de un mecanismo (como la consignación en derecho actual) ${ }^{27}$ que atemperase por un lado el interés del deudor a su liberación y por otro, que garantizase al acreedor su derecho a la prestación debida; por ello , ante un sentimiento fuerte de protección al deudor, debido a la situación de indefensión absoluta existente en el Derecho arcaico, se le facultaría el recurso a prácticas hoy en día injustificables, como el abandono del objeto debido ${ }^{28}$.

Paralelamente a la evolución de la doctrina de la mora del acreedor que se inicia en la época clásica, se va produciendo un debilitamiento en la facultad reconocida al deudor de obtener su liberación mediante el abandono del objeto debido.

Esta idea se encuentra recogida en un texto de Labeón (D. 18.1.50) citado por Ulpiano (lib. XI ad Edictum): Labeo scribit, si

${ }^{26}$ Según la traducción de Benítez LóPEz, op. cit., p. 176.

${ }^{27}$ La palabra mecanismo aparece a lo largo de toda la obra de Cano HuRTAdo, op. cit., como la elegida para introducir un término suficientemente expresivo de la situación o remedio inventado para hacer frente a las situaciones provocadas por la mora del acreedor.

${ }^{28} \mathrm{La}$ facultad de abandono del objeto debido se recoge en la actualidad únicamente en el Derecho alemán, bajo ciertas condiciones; según el § 303 BGB:

Si el deudor está obligado a entregar la posesión de una finca o una embarcación registrada o una embarcación que esté siendo construida, puede abandonar su posesión después de la aparición de la mora del acreedor. El acreedor debe ser avisado previamente del abandono, a menos que el aviso resulte impracticable (utilizo la traducción de E. EIRANOva Encinas, Código civil alemán comentado, Marcial Pons, Madrid, 1998). 
mihi bibliothecam ita vendideris, si decuriones Campani locum mihi vendidissent, in quo eam ponerem, et per me stet, quominus id a Campanis impetrem, non esse dubitandum, quin praescriptis verbis agi possit; ego etiam ex vendito agi posse puto quasi impleta conditione, quum per emptorem stet, quominus impleatur ${ }^{29}$.

Se trataba de un supuesto de compraventa de una biblioteca sometida a condición suspensiva potestativa (si me vendieras una biblioteca si los Decuriones Campanos me hubiesen vendido lugar para ponerla) que no puede realizarse por culpa del comprador (y consistiera en mi que yo esto no lo impetre de los Campanos), se permite que el vendedor pueda actuar como si la condición se hubiera verificado. El hecho de no procurar el local en el que colocar la biblioteca adquirida va a constituir una violación del deber de cooperación que incumbe al acreedor (comprador de los libros), y por lo tanto genera la mora creditoris. La consecuencia es que el deudor (vendedor) tendría derecho a obtener el precio. Y es así tal y como expresa Labeón: "no se ha de dudar que puede ejercitarse la actio praescriptis verbis; y yo creo que también puede intentarse la actio venditi como si se hubiera cumplido la condición, cuando consista en el comprador que no se cumpla».

Por lo tanto, ante la situación descrita se facultaba al deudor un remedio procesal; la posibilidad de interponer no sólo una actio, sino dos. La de lo expresado con las palabras y la del vendedor ${ }^{30}$. Pero no se menciona la posibilidad de abandonar que antiguamente se reconocía al deudor.

Frente a la idea que imperaba en la época anterior que consideraba que el deudor no estaba obligado a garantizar la prestación tras la mora del acreedor, y por lo tanto la conservación de la misma era meramente facultativa (por lo que el acreedor no estaba obligado a indemnizar los gastos realizados por el deudor), en época clásica aparece una nueva concepción de la mora creditoris ${ }^{31}$. El Digesto recoge el supuesto en que habiendo incurrido en mora el acreedor, y tratándose de una obligación alternativa ${ }^{32}$, el esclavo falleciera por un

\footnotetext{
${ }^{29}$ Utilizo siempre la versión de la traducción de GARCÍA DEL CORRAL.

${ }^{30}$ Sobre estas acciones y en el marco procesal, puede verse lo relativo a las mismas en los manuales de Derecho romano; sobre la controversia del por qué y el cómo fue introducida la actio praescriptis verbis, y la consideración de que se hallan interpolados los textos justinianeos que se refieren a ella, véase ARIAS RAMOS-ARIAS BONET, Derecho Romano, II, pp. 633-637; sobre la actio venditi, p. 652.

${ }^{31}$ Cano Hurtado, op. cit., p. 31.

${ }^{32}$ Son aquellas en que se señalan varias prestaciones para que el deudor cumpla sólo una de ellas, bien a elección suya o bien elegida por el acreedor. En general, y
} 
hecho ajeno al deudor. En este caso el deudor será liberado, no porque el acreedor se hubiera retrasado en la recepción del objeto, tampoco porque se hubiera abandonado, sino porque durante la situación de mora accipiendi, la prestación ha quedado destruida por un hecho no voluntariamente causado por é ${ }^{33}$ :

Stipulatus sum, Damam aut Erotem servum dari; quum Damam dares, ego, quominus acciperent, in mora fui; mortus est Dama, an putes, me ex stipulatu actionem habere? Respondit, secundum Masurii Sabini opiniones puto te ex stipulatu agüere non posse; nam is recte existimabat, si per debitorem mora non esset, quominus id, quod debebat, solveret, continuo eum debito liberari ${ }^{34}$.

En relación con las obligaciones alternativas, cuando la elección correspondía al acreedor, la reducción de posibilidades electivas y consiguiente concentración de la obligación solamente acaecía cuando la desaparición de los objetos se debía al caso fortuito o culpa del mismo acreedor (como en este caso); si la culpa era del deudor, continuaba la facultad d elegir, aunque, naturalmente versase, respecto al objeto desaparecido, sobre su estimación pecuniaria.

Tales reglas fueron modificadas en Derecho justinianeo estableciéndose $\mathrm{e}^{35}: 1^{\mathrm{o}}$, que el deudor, cuando la obligación le correspondía, podía cumplir la obligación pagando la aestimatio de la prestación que se hizo imposible por caso fortuito; y $2^{\circ}$, que en el caso de que la obligación no pudiera cumplirse porque una o más prestaciones se hicieran imposibles por culpa del deudor y la última por caso fortui-

salvo que las partes hubieran acordado una duración determinada del ius electionis, el momento hasta el cual subsistía la facultad de rectificar la elección del objeto (ius variandi) era normalmente, tanto par el acreedor como para el deudor, el del pago efectivo. Por otra parte, el concepto de obligación alternativa como figura unitaria abstracta es elaboración de la dogmática moderna. Los juristas romanos trataron con independencia los distintos tipos concretos en base a las diferencias en cuanto al enfoque procesal de las relaciones jurídicas. Por ello en las stipulationes se consideraba la irrevocabilidad de la primera elección una vez hecha, y, la elección aceptada por el otro sujeto se consideraba como pacto de non petendo respecto de las otras prestaciones no elegidas (ARIAS RAMOS-ARIAS BONET, Derecho Romano, II, pp. 572-573). Sobre la inconveniencia del concepto unitario, incluso para el jurista actual, véase A. D'Ors, $R D P, 1994$, pp. 1 ss.

${ }^{33}$ Se trata de D. 45. 1. 105, Iavolenus lib. 2 epist.

${ }^{34}$ Estipulé que se me daría el esclavo Damas o Eros, al darme tú el esclavo Damas fui moroso en recibirlo; murió Damas, ¿opinas que tengo la acción de lo estipulado? Respondió que, según el parecer de Masurio Sabino, opinaba que no podías ejercitar la acción de lo estipulado; porque él opinaba con razón, que si en el deudor no hubiese habido morosidad en pagar lo que debía, él quedaba inmediatamente libre de la deuda.

${ }^{35}$ Parece ser que por medio de interpolaciones. 
to, pudiera ejercitarse contra el deudor la actio de dolo, destinada en general a reparar un perjuicio injusto imputable al demandado ${ }^{36}$.

Se podría decir que a través de una lenta evolución se fue consolidando la obligación del deudor de evitar un perjuicio económico en la parte del acreedor, lo que se pudo traducir en la progresiva extinción del principio del abandono de la cosa debida como medio para obtener su liberación, llegando a desaparecer a finales del siglo primero de nuestra era tal y como ilustran algunos fragmentos de las fuentes ${ }^{37}$. Siguiendo esta idea, algunos autores afirman la existencia de un principio de responsabilidad del deudor una vez surgida la mora del acreedor, aunque limitándola al dolo o la culpa grave ${ }^{38}$, por lo que fuera de estos supuestos, el riesgo correría a cargo del acreedor, si bien tendría derecho al reembolso de los gastos realizados y al resarcimiento del daño causado ${ }^{39}$. Ante esta situación, sería necesaria la adopción de otras medidas que salvaguardando los intereses del acreedor, procurasen sin embargo, la liberación del deudor. Para satisfacer dicha necesidad es probable que hiciera su aparición el depósito con efecto liberatorio, aunque ignoramos si en ese caso fue necesario el cumplimiento de determinados requisitos.

\section{LA APARICIÓN DEL DEPÓSITO CON EFECTOS LIBERATORIOS PARA EL DEUDOR}

Determinar el momento en el que el depósito con fines liberatorios, (es decir, con efectos de pago) surge, es cuestión muy debatida ${ }^{40}$. Para Solazzi solo en determinados supuestos podría considerarse que tendría ese efecto, y en base a justas causas: cuando el acreedor rechazase el ofrecimiento de pago; en caso de minoría de edad del acreedor, pues se corre el peligro de que el pago se considere inválido

\footnotetext{
${ }^{36}$ Arias Ramos-Arias Bonet, Derecho romano, II, p. 574.

${ }^{37}$ Se trata de D. 19. 1. 38. 1; D. 30. 84. 3; D. 40. 5. 47. 2; D. 18. 6.18.

${ }^{38}$ Sobre estas ideas, ARIAS Ramos-ARIAS Bonet, op. cit., pp. 585-587; LozANO CoRBI, Historia e instituciones de derecho romano, Zaragoza, 1999, pp. 444 y 462 ss.

${ }^{39}$ Riccobono, op cit., p. 457 y Lozano CoRBI, op. cit., p. 466.

${ }^{40}$ En este sentido Solazzi, L'estinzione dell'obligazione nel Diritto romano, vol. 1, Napoli, 1935, p. 40, señalaba que « ...L'uso di depositare in luogo pubblico, specialmente in un templo, l'oggetto che non si può o non si vuole per giuste ragione prestare al creditote, è attestao in varii luoghi delle fonti giustinianeee. Si recorre al deposito, quando il creditote rifiuta di recevere il pagamento; quando per la minore età del creditote c'è il pericolo che il pagamento sia invalidato dalla restitutio in integrum, quando il pagamento sia impossibile per l'assenza del creditote o per la incertezza sulla persona del creditote o per difetto di autorizzazione nel rappresentante del creditote...»
} 
y se acuda a la restitutio in integrum ${ }^{41}$; cuando el cumplimiento sea imposible por ausencia del acreedor o por desconocimiento de la persona del acreedor o por un defecto en la autorización al representante del acreedor ${ }^{42}$.

El depósito con fines liberatorios para el deudor parece ser resultado de un lento proceso a lo largo del tiempo, y en el que intervienen los argumentos de auctoritas de diferentes juristas. Los mayores problemas se encuentran en el hecho de que las fuentes de las que se parte para su estudio, pueden haber resultado interpoladas en ocasiones, lo que provoca discrepancias entre los romanistas a la hora de su interpretación y ubicación cronológica. Por ello existen varias corrientes doctrinales que intentan determinar fielmente, a veces con criterios opuestos, los efectos del depósito de la cosa debida.

No parece ser objeto de discusión la consideración de que en derecho clásico los intereses por haber incurrido el deudor en mora cesaban con el simple ofrecimiento ${ }^{43}$ al producirse la purgatio morae ${ }^{44}$. Sin embargo, sería necesario el depósito para que cesara el curso de la usurae. Es decir, el depósito se realizaría después de haber ofrecido la pecunia debita al acreedor y, tras su rechazo, haber procedido a la obsignata. Por tanto, para conseguir que no existieran intereses debería haberse procedido a la realización de tres actos: la oferta (oblatio), el sellado o guarda de las cosas ofrecidas como cumplimiento de la obligatio (obsignatio), y el depósito (depositio). No bastando cualquiera de ellas por si sola para conseguir ese efecto, es decir, que no surjan intereses por mora del deudor ${ }^{45}$.

${ }^{41}$ Es sin duda éste uno de los clásicos supuestos de restitutio in integrum (D. 50. 1. 26 pr. y 1). Véase Sentencias de Paulo, 1,7 y D. 4. 1 De in integrum restitutio. Sobre actos magis imperium quam iurisdictionis, URSICINo Álvarez, Curso de Derecho romano, t. I, Madrid, 1955, pp. 487 y 522-528.

${ }^{42}$ Con las reservas que suscita en Roma la adquisición por parte del representante. Véase Gayo, 2, 95 y PS, 5, 2, 2. Ni aun en la fase bizantina se llegó a un reconocimiento pleno del principio de la representación perfecta o directa. La impropia, mediata o indirecta es la única reconocida por el Derecho romano (ARIAS RAMOS-ARIAS BONET, op. cit., I, p. 152).

${ }^{43}$ Magdelain, Note sur la Purgatio morae, en Droit de l'antiquité et sociologie juridique (Melanges H. Levy-Bruhl)Paris, 1959, p. 200.

${ }^{44}$ D. 45, 1, 91, 3. La purgatio morae es un modo de extinción de la mora debitoris que consiste en el ofrecimiento que hace el deudor moroso al acreedor del capital debido con sus intereses (usurae moratoriae), que el acreedor no podía rehusar sin justo motivo (TorRent, Diccionario cit.).

${ }^{45}$ La obligación de pagar intereses a partir de la mora puede observarse en PS, 2,17,9: post rem traditam nisi emptor pretium satatim exsolvat, usuras eius praestare congendus est, y Ulpiano en D.19, 1, 13, 20; intereses siempre exigibles en los créditos pecuniarios (usurae ex mora). Esto es, en las obligaciones que consistían en que el 
Frente a esta opinión mayoritaria, otro sector representado por De Ruggiero, sostiene que para que se produjera el cese de los intereses bastaría con dos actos: oblatio y obsignatio, ya que si la razón por la que el deudor es liberado de la obligación de los intereses cuando deposita es que se le priva del uso del dinero no pudiendo ya obtener ventajas, ni correspondiéndole los frutos, la misma consecuencia se conseguiría mediante la oblatio y la obsignatio sin necesidad de acudir al depósito ${ }^{46}$. Sin embargo Solazzi piensa que no se podría considerar que ha cesado la usurae cuando falta la certeza de que el dinero no está a disposición del deudor; existiendo esa certeza plenamente cuando tras haber hecho la oferta (oblatio), el dinero se introduce en el sacculus (obsignatio) y posteriormente se procede a su depósito (depositio). Si faltara ese último acto, faltaría la certeza exigida, incluso aunque la oblatio y la obsignatio se realizaran en presencia de testigos, ya que no se podría constatar de ninguna forma que con posterioridad el deudor no utilizara lo introducido en el sacculus $^{47}$.

Este último criterio señalado parece el más idóneo para realizar una aproximación al estudio de la consignatio.

Respecto al lugar donde debía depositarse la cosa debida, parece que no se requería un lugar público bajo el control del magistrado, ya que el depósito en esos casos no diferiría del ordinario y el deudor era libre para elegir el lugar en el que lo llevaría a cabo. En este sentido nuevamente se pronuncian Solazzi y Bove ${ }^{48}$. Por su parte Quintana señala que de forma excepcional se requeriría la realización del depósito en un templo, y ello a tenor de un fragmento del Digesto que lo justifica en base a la menor edad del acreedor ${ }^{49}$. Para Cano Hurtado, y con apoyo en la tesis de Bove ${ }^{50}$, en época clásica, el depósito de la

deudor debía pagar una cantidad de dinero, su retraso en el cumplimiento (mora debitoris) implicaba automáticamente el pago sobreañadido de intereses moratorios en las obligaciones que daban lugar a bonae fidei iudicia (Marciano en D. 22,2,32, 2: in bonae fidei contractibus ex mora usurae debentur), obligación que Justiniano extendió a todo tipo de obligaciones. En este sentido entre nosotros, los manuales de Derecho romano de PANERo, IgLESIAS, D'ORS, por todos, y HERRERA, Usurae: problemática jurídica de los intereses en Derecho romano, Jaén 1997.

${ }^{46}$ De Ruggiero, Considetto deposito pubblico o giudiziale in Diritto romano, en Studi Economico-giuridico dell'Università Cagliari, I, 1909, p. 149-150.

${ }^{47}$ SolazzI, op. cit., p. 144.

${ }^{48}$ SolazzI, op. et loc. cit.; Bove, Gli effeti del deposito della cosa dovuta, en Labeo, 1955, pp. 175-176, aunque este autor matiza que salvo en el supuesto de ausencia del acreedor donde se haría necesaria la presencia del magistrado por razones obvias.

${ }^{49}$ Quintana Orive, op. cit, p. 446 se refiere a D. 4. 4. 7. 2.

${ }^{50}$ Bove, voz «Offerta reale», en Enc. Dir., vol. XXIX, Milano, 1979, p. 774. 
cosa debida, no sería diferente del ordinario puesto que no se realizaría en lugar público, ni por orden, ni bajo el control del magistrado, y produciría el cese del curso de la $u s u r a e^{51}$. Por el contrario De Ruggiero y Catalano ${ }^{52}$ son de la opinión de que el depósito debería hacerse en lugar público, postura bastante convincente, ya que en mi opinión, solo así se conseguirían los efectos de publicidad y liberatorios perseguidos, y ante la dificultad probatoria del hecho de la oblatio y la obsignatio.

En todo caso, la aparición del depósito con efectos liberatorios para el deudor, es un tema muy debatido por la doctrina romanística al considerarse que los textos bien podrían haberse visto sometidos a interpolaciones ${ }^{53}$.

De Ruggiero sostiene que en época clásica existirían dos tipos de depósito, uno privado y otro público o judicial. El judicial tendría la particularidad de generar la extinción y por tanto la liberación del deudor; precisamente por ello se trataría de un depósito irrevocable para el deudor. En su opinión éste sería el conservado en la Compilación Justinianea ${ }^{54}$. Pero para otros autores ${ }^{55}$, el momento clave en esta institución lo hallaríamos con Diocleciano, que representaría el punto clave en el que debió producirse una renovación en el concepto del depósito existente hasta entonces, considerando que solo a partir de dicho emperador, debió de producirse la extinción de la obligación, y por tanto, los efectos liberatorios. Esta idea aparece en diversos rescriptos. Por ejemplo el contenido en Codex, 8, 42, (43), 9 del año 286:

Impp. Diocletianus et Maximianus AA. Cassio: Obsignatione totius debitae pecuniae solemniter facta liberationem contingere, manifestum est. Sed ita demum oblatio debiti liberationem parit, si eo loco, quo debetur, fuerit celebrata (Es evidente, que con el depósito de toda cantidad adeudada hecho solemnemente se verifica la liberación. Pero la oferta de lo adeudado produce la liberación solamente si se hubiere hecho en el lugar en que se debe el pago), de donde parece que el depósito de la cosa debida produce la extinción de la obligación y por tanto la liberación del deudor.

${ }^{51}$ CANO Hurtado, op. cit., p. 34.

${ }^{52}$ De Ruggiero, op. cit, p. 125 ss; Catalano, Sul deposito della cosa dovuta in Diritto romano, en Annali del Seminario guridico, vol. III, Napoli, 1949, pp. 512 ss.

${ }^{53}$ Cano Hurtado, op. et loc. cit.

${ }^{54}$ DE Ruggiero, op. cit., p. 121-186.

55 Bove, Catalano, op cits., y KaSeR, Derecho romano privado (trad. española J. Santa Cruz TeiJeiro), 2a ed., Reus, 1968, p. 237. 
Sin embargo, la expresión solemniter facta en el texto, hace referencia a la solemnidad con que debe realizarse el depósito para que tenga esos efectos liberatorios. No bastaría pues un depósito sin más, ordinario, sino revestido de algo más ${ }^{56}$. De ahí que en opinión de Solazzi, este texto daría lugar a la interpretación siguiente: una vez depositada solemnemente la cosa debida tiene efecto liberatorio, por lo que el deudor depositante no podría ejercer la actio depositi ${ }^{57}$. Por tanto se trataría de un depósito irreversible para el deudor, postura que coincide abiertamente con la esgrimida por De Ruggiero y señalada anteriormente. En mi opinión, dicha actio, en su versión de actio util, pasaría a ser considerada como facultad para ser esgrimida contra el depositario por el acreedor en un proceso que podríamos considerar de jurisdicción voluntaria. Por otra parte la sola oblatio, no parece que tendría efectos liberatorios salvo que se hubiere hecho en el lugar en que se debiese el pago, según el texto.

Otro rescripto de los mismos emperadores, bastante posterior (293-305) parece señalar que para producir dicho efecto liberatorio sería necesario que el depósito se realizara en lugar público o en el ordenado por el juez competente al que se hubiera acudido. Se trata de Codex 4,32,19, pr., que por su interés reproduzco íntegramente ${ }^{58}$ y que quizá represente el solemniter facta exigido en el rescripto anterior:

Impp. Diocletianus et Maxiamianus AA. et CC. Hyreniae: Acceptam mutuo sortem cum usuris licitis creditori post testationem offer; at si non suscipiat, consignatam in publico depone, ut cursus legitimarum usurarum inhibeatur. In hoc autem casu publicum intelligi oportet sacratissimas Aedes, vel ubi competens iudex super ea re aditus deponi eas disposuerit. Quo subsecuto etiam periculo debitor liberabitur, et ius pignorum tollitur quum Serviana etiam actio manifeste declaret, pignoris inhiberi persecutionem vel solutis pecunias vel si per creditorem steterit, quominus solvantur: quos etiam traiectitiis servari oportet;

\footnotetext{
${ }^{56}$ ¿forma quizá?, ¿lugar público?, las solemnidades exigidas en épocas pasadas, se veían satisfechas por ceremonias de signo contrario como por ejemplo en el caso de la mancipatio, por una reemancipatio, pero ninguna de ellas se ha conservado en esta época, por lo que sorprende la necesidad de un acto revestido de solemnidad, a pesar del solemniter facta recogido en las fuentes.

${ }^{57}$ SolazZI, Op. cit., p. 150.

${ }^{58} \mathrm{~A}$ pesar de que no han faltado voces que sugieren que el texto está interpolado. En este sentido SolAzzI, op. cit, p. 145, considera que es evidente por la expresión in publico, ya que en esta época el deudor tendría la posibilidad de realizar el depósito donde considerase oportuno (y ante el depositario que prefiriese). Si fuera así podría afirmarse que el compilador justinianeo posiblemente creyó más adecuado añadir esa exigencia e efectos de veracidad de la consignatio (y posiblemente de otros actos de jurisdicción voluntaria).
} 
creditori scilicet actione utili ad exactionem earum non adversus devitorem, nisi forte eas receperit, sed contra depositarium vel ipsas competente pecunias.

\section{ANÁLISIS DEL RESCRIPTO}

Son diversas las cuestiones que aquí se plantean. En primer lugar cabría decir que a partir de Diocleciano se instaura la que podemos llamar época postclásica en la llamada «vida del derecho romano», se hace necesario que el depósito se realice en lugar público (sacratissimas aedes vel ubi competens iudex), lo que evidencia una evolución respecto al sistema anterior (época clásica) donde bastaría con depositarlo donde el deudor considerase oportuno y ante quien considerase oportuno ${ }^{59}$, por lo que no podría hablarse en dicho período de un depósito público-judicial ${ }^{60}$, en el sentido actual del término.

La exégesis del texto no pretende tener características filológicas y sí tan sólo plantear, que aunque diversos autores han considerado la interpolación de los textos, en todo caso hay que tener una dosis de prudencia al hablar de las mismas ${ }^{61}$, si bien, consultado el Index ${ }^{62}$, ciertamente se encuentran ambas constituciones entre las consideradas como interpoladas ${ }^{63}$. Pero ¿a qué solemnidades se refería el rescripto anterior? ¿a la presencia de testigos? Tampoco este rescripto nos lo aclara.

Diferentes autores ${ }^{64}$ señalan a Diocleciano como el emperador con el que se produce una modificación en el depósito cuando lo que se pretende es obtener la liberación del deudor, ya que en este caso, no bastaría realizar un depósito ordinario, sino que debería llevarse a cabo en lugar público, bajo las órdenes del magistrado o en su caso del juez. Esta innovación ${ }^{65}$ fue conservada por los compiladores justinianeos, seguramente por resultar de interés práctico.

${ }^{59}$ SolazzI, op. et loc. cit.

${ }^{60}$ Cano Martínez De Velasco, La mora, Madrid, 1978, p. 4.

${ }^{61}$ KASER, Las interpolaciones, Comarés, Granada, 1999.

${ }^{62}$ Index Interpolationum quae in Iustiniani codice inesse dicuntur (IIC), Ed.cur. BRogginI, Böhlau, Verlag, Köln, Wien, 1969.

${ }^{643}$ IIC, pp. 136 y 80.

${ }^{64}$ Bove, Catalano, op. et loc. cits.

${ }^{65}$ En este sentido, Bove, Catalano, op. et loc. cits. En contra ASTUTI, voz «Deposito» en Enc. Dir., t. XII, 1964, p. 222. 
En este sentido Catalano matiza que no bastaría con una simple autorización u orden del magistrado para proceder al depósito, sino que el depósito judicial no produciría sus efectos liberatorios si no se realizara bajo un procedimiento de carácter administrativo o jurisdiccional que impregnaría al depósito de su carácter público-judicial (solemniter facta), de la misma manera que se prevé en la regulación actual ${ }^{66}$. Pero frente a esta posición se encuentran todos aquellos que posponen hasta época justinianea la aparición del depósito con efectos liberatorios.

En mi opinión, las constituciones imperiales señaladas constituyen base suficiente para considerar como momento relevante la figura del emperador Diocleciano. Y por otra parte, si a los compiladores justinianeos no les hubiesen parecido de interés para solucionar cuestiones que seguramente ya se daban en la práctica, habrían prescindido de ellas; por el contrario, el que se encuentren recogidas en el Codex es una muestra de su valor.

\section{El depósito de la cosa debida ¿implicaba la pérdida de la actio depositi para el deudor depositante?}

Este es sin duda un tema muy discutido por la doctrina. Si la respuesta es afirmativa, y por tanto el deudor pierde la actio depositi, ello convertiría el depósito en irrevocable y por tanto produciría efectos liberatorios para el deudor. Dicha postura es la mantenida por De Ruggiero, quien sostiene que en época clásica ya existía la posibilidad de un depósito público o judicial de la cosa debida, voluntario o efectuado por orden del magistrado. No es posible conciliar los efectos liberatorios que dicho depósito producía si no es afirmando su irrevocabilidad. Es decir, si el depósito producía efectos liberatorios era precisamente porque se le privaba al deudor de dicha acción una vez hubiere depositado en lugar público ${ }^{67}$. Sin embargo, Solazzi, conside-

${ }^{66}$ Catalano, op. cit., p. 519.

${ }^{67}$ De Ruggiero, op. cit., pp. 161-179, donde analiza diversos fragmentos de las fuentes como fundamento de su afirmación. Se trata de D. 17,1, 56, 1; D. 46, 1, 64; D. 40, 7, 4,pr. (el statuliber, esto es el esclavo manumitido en testamento (por manumissio indirecta), se considera que consigue inmediatamente la libertad en cuanto deposita el dinero en lugar público (cumplimiento de la condición suspensiva); en este caso se trata del supuesto de que el heredero al que se le ruega que conceda la libertad al esclavo estuviese ausente por causa de la república) y D. 40, 5, 47, 2. Igualmente CATALANo y Astuti, op. et loc. cits. En estos casos se pone de manifiesto cómo el pretor no habría procedido a conceder la libertad si no fuera porque el depósito era irrevocable, ya que de lo contrario se trataría de un cumplimiento ficticio. 
ra que sólo en época justinianea se podría hablar de efecto liberatorio de depósito de la cosa debida ${ }^{68}$ en base a diversos fragmentos de las fuentes ${ }^{69}$, que evidenciarían la facultad del depositante de disponer de la cosa depositada en el momento que quisiera (por lo tanto sería revocable), y teniendo la posibilidad de ejercitar la actio depositi.

Otro aspecto relacionado con este tema es considerar la posibilidad de que al acreedor se le concediese una actio utilis que dirigiría contra el depositario para poder reclamar la cosa depositada. No parece haber discusión en la doctrina ${ }^{70}$ a la hora de considerar la época justinianea como el momento histórico en el que le fue concedida al acreedor una actio utilis que le permitiera reclamar al depositario la cosa objeto del depósito, en base al siguiente texto considerado también como interpolado ${ }^{71}$ :

Codex, 4, 32, 19, 4: (...) creditori scilicet actione utili ad exactionem carum non adversus debitorem, nisi forte eas receperit, sed contra depositarium vel ipsas competente pecunias, (competiéndole al acreedor la acción útil para la exacción de estas cantidades no contra el deudor, si acaso no las hubiere recibido, sino contra el depositario o contra el mismo dinero).

Precisamente Solazzi, líder de la postura a favor de considerar en dicha época la configuración del depósito con efecto liberatorio, rea-

${ }^{68}$ La discusión doctrinal puede verse en el trabajo de CANO HuRTADO, La consignación como mecanismo, cit., p. 37 ss.

${ }^{69}$ En realidad se trata del fragmento contenido en D. 22, 1, 7, donde se recoge la hipótesis en la que un deudor, que debía también intereses, ofreció al acreedor el importe de la deuda y no habiéndolo querido recibir, lo selló y lo depositó; desde este día no se tendrá en cuenta los intereses. Pero si demandado después para que pagase hubiere incurrido en mora, a partir de dicho momento, estaría obligado al pago de los intereses y la obligación no se habría extinguido. En su opinión, este supuesto estaría reconociendo implícitamente la facultad al deudor (depositante) de poder retirar la cosa depositada interponiendo la actio depositi frente al depositario (Solazzi, op. cit., p. 155).

${ }^{70}$ Aunque Bove, Gli effeti del depositi, cit., pp. 186-187, fiel a su postura de considerar a Diocleciano como punto de inflexión en la configuración del depósito, opina que fue este emperador el que concedió también al acreedor la actio utilis; y ello en relación con la idea que mantiene de que fue bajo su imperio cuando el deudor pudo ejercer la actio depositi (directa). Igualmente Herrera Bravo, op. cit., p. 447. Sin embargo KASER, Derecho romano privado, cit., p. 237, siendo también partidario de la tesis que considera a Diocleciano el punto clave para considerar que el depósito produce efectos liberatorios, sostiene que la actio utilis se concede al acreedor en época justinianea.

${ }^{71}$ C. 4,32,19,4 (en la ed. de KRÜGER para cfr. el Index Interpolationum quae in Iustiniani codice inesse dicuntur según Ferrini, Gradenwitz, Mancaleoni, Perozzi, SoLAZZI y en sus obras citadas en el IIC, p. 81. 
liza una fuerte crítica a aquellos que mantienen que fue en el derecho clásico cuando surgió esta concepción del depósito atribuyéndole carácter irrevocable, y privando, por lo tanto al deudor de la actio depositi. Manifiesta que no es posible admitir la irrevocabilidad del depósito de parte del deudor-depositante, si al mismo tiempo no se da una acción al acreedor para poder retirar el depósito realizado. En definitiva afirma que al Derecho justinianeo se le deben dos importantes innovaciones: que el depósito pasa a ser realizado en un lugar público por razones de seguridad y, la concesión al acreedor de la $a c$ tio utilis que podrá ejercitarla si el deudor no ha hecho uso de su actio depositi. Por ello en época justinianea el depósito producirá efectos liberatorios siempre que el deudor no ejercite la actio depositi, ya que en ese caso la obligación renacería ${ }^{72}$.

En definitiva, las cuestiones doctrinales planteadas, y magníficamente recogidas en el trabajo de Cano Hurtado ${ }^{73}$, no deberían distraer nuestra atención, sino llevarnos a la conclusión de que lo que sí es cierto es que se produjo una transformación en el depósito con fines liberatorios para el deudor, y que se llevó a cabo en base al cumplimiento de algunas solemnidades como por ejemplo, el acudir a un lugar público para realizarlo.

\section{OTRAS CONSIDERACIONES SOBRE CONSIGNATIO DE LA COSA DEBIDA Y DEPÓSITO LIBERATORIO EN LAS FUENTES}

A continuación se pretende al examinar algunos supuestos de consignación, mostrar que en todos los casos, y con base en las fuentes, nos hallamos ante actos conocidos como de jurisdicción voluntaria, denominación hallada en un fragmento de Marciano contenido en el Digesto, que ha sido estudiado en profundidad por el profesor D. Antonio Fernández de Buján ${ }^{74}$.

${ }^{72}$ Cano Hurtado, op. cit., p. 38, y ampliamente, C. García VÁzQuez, Extinción de la responsabilidad por depósito o consignación de cosa debida, en La responsabilidad civil. De Roma al derecho moderno, IV Congreso Internacional y VII Congreso iberoamericano de Derecho romano, Burgos, 2001, pp. 415-428.

${ }^{73}$ Cano Hurtado, op. cit., pp. $34-38$.

${ }^{74}$ Bibliografía sobre jurisdicción voluntaria, en Derecho romano, y Derecho procesal vigente, puede verse de D. Antonio Fernández de Buján, todas las obras mencionadas en su extensa nota 3 a pie de página, en Protección patrimonial de las personas con discapacidad y jurisdicción voluntaria, página 193 y 194 de la obra colectiva La protección Jurídica del discapacitado, II Congreso regional, Tirant lo blanch, Valencia 2007. Otros autores en la misma obra, pp. 195 y 196, en notas a pie, 4 y 5. No es ob 
La lectura de D. 46, título 3 De solutionibus et liberationibus nos aproxima al régimen jurídico de los pagos y de las liberaciones. Si nos detenemos en el fragmento 30, Ulpiano, Comentarios al Edicto, libro 51 , nos dice textualmente que si el deudor ofreciese el dinero que se le pidiera, y el acreedor no quisiera recibirlo, el pretor le deniega a éste las acciones (si debitor oferret pecuniam, quae peteretur, creditor nollet accipere, Praetor ei denegat acciones) por lo que cabe deducir que si se depositara dicha cantidad en el templo u otro lugar, el deudor se liberaría de la obligación, pues ésta ya no puede ser exigida por el acreedor por medio de una acción, que es el medio idóneo para ello en caso de incumplimiento.

Parece que desde finales de la época republicana, la solutio, producía el efecto de extinguir todo tipo de obligación una vez procurada la satisfacción del acreedor. Como se señala en D. 50, 16 ${ }^{75}$, 176, fragmento de Ulpiano, Comentarios a Sabino libro 45: Solutionis verbo satisfacciones quoque omnem accipiendam placet, solvere dicimus eum, qui fecit quod facere promisit (Se conviene que la palabra pago -solutio- comprende toda satisfacción, y decimos que paga aquel que hizo lo que prometió hacer).

La solutio implicaba que el deudor ejecutara el comportamiento debido y ejecutara cabalmente su prestación, en cuyo caso la obligación quedaba extinguida ipso iure. En las obligaciones de dare los juristas construyeron el pago como negocio traslativo de la propiedad de la cosa debida, viendo su causa en la voluntas de las partes dirigida a extinguir la obligación. El pago debía ser causal, dejando aparte negocios abstractos como la mancipatio y la in iure cessio en los que su valor formal con efectos inmediatos permitía hacer abstracción de la causa, y lo mismo ocurría en la traditio solvendi causa; pero si se demostraba la inexistencia de la obligación, el deudor podía reclamar lo pagado mediante la condictio indebiti dirigida a deshacer un desplazamiento patrimonial sin causa (solutio indebiti), no surgiendo aparentemente más problemas. La cuestión se plantea, cuando a pesar de ello no se considera extinguida la deuda (o se tratara de otro tipo de obligaciones) surgiendo la necesidad de ponerse en marcha el mecanismo de la consignatio cuyos requisitos han sido considerados.

jeto de este trabajo dar una bibliografía exhaustiva sobre dicho tema, por lo que remito al Autor, referencia obligada en esta materia.

También FERnÁndez de BuJán A., Derecho Público Romano, 12 $2^{\mathrm{a}}$ edición, Civitas Thomson Reuters, sobre todo, pp. 390-428; la bibliografía en pp. 424-428.

${ }^{75}$ Obsérvese que el título 16, está dedicado al significado de las palabras. 
Para que pueda darse la consignatio deben producirse una serie de actos previos necesarios e imprescindibles como son: el ofrecimiento de pago y la negativa del acreedor a admitirlo o la imposibilidad de realizarlo en base a distintas causas. Estas son: minoría de edad del acreedor, pues se corre el peligro de que el pago se considere inválido y se acuda a la restitutio in integrum ${ }^{76}$; imposibilidad por ausencia del acreedor, por desconocimiento de la persona del acreedor, o por un defecto en la autorización al representante del acreedor.

\section{Quiénes están facultados para recibir el pago}

La regla general es que la legitimación para recibir el pago corresponde esencialmente al acreedor, pero puede estar legitimado un tercero autorizado por el acreedor, como el procurador en la delegatio dandi, o un servus pecuniis exigendi praeposito ${ }^{77}$, o cualquier tercero designado para recibir el pago: adiectus solutionis causa ${ }^{78}$; que incluso podía ser un incapaz ${ }^{79}$. En otros casos el ordenamiento pre-

${ }^{76}$ Es sin duda este uno de los clásicos supuestos de restitutio in integrum (D. 50. 1. 26 pr. y 1). Véase Sentencias de Paulo, 1, 7 y D. 4. 1 De in integrum restitutio. Sobre actos magis imperium quam iurisdictionis, URSICINo Álvarez, Curso de Derecho romano, t. I, Madrid, 1955, pp. 487 y 522-528.

${ }^{77}$ D. 13, 7, 11, 5 Ulp: Solutam autem pecuniam accipiendum non solum si ipsi, cui obligata res est, sed et si alii sit soluta voluntate eius, vel ei, cui heres extitit, vel procuratori eius, vel servo pecuniis exigendis praeposito (Mas ha de entenderse pagada una deuda, no solamente si se pagó al mismo a quien se obligó la cosa, sino también si a otro con su voluntad, o al que fue su heredero, o al procurador de él, o al esclavo encargado de cobrar cantidades).

${ }^{78}$ D. 46, 3, 11 Pomp. lib. 4 ad Sabinum: Si estipulatus fuero: "mihi aut pupillo dare?" promissor sine tutoris auctoritate solvendo pupillo liberabitur a me(Si yo hubiere estipulado: ¿¿prometes darme a mí o al pupilo?» pagándole el prometedor al pupilo sin la autoridad del tutor, quedará libre respecto a mí).

D. 46, 3, 9 pr. Ulp.lib.4 ad Sabinum: Stipulatus sum, mihi aut Sticho servo Semproni solvi; Sempronio solvi non potest, quamvis dominus servi sit (Estpulé que se me pagara a mí o a Stico, esclavo de Sempronio; no se le puede pagar a Sempronio, aunque sea dueño del esclavo).

${ }^{79}$ D. 45, 1, 56, 2 Jul. lib.52 Digestorum: Qui sibi aut filio suo dari stipulatur, manifeste personam filii in hoc complectitur, ut ei recte solvatur; neque interest, sibi, aut extraneo cuilibet, an sibi, aut filio suo quis stipuletur; quare vel manente in potestate, vel emancipato filio recte solvitur; neque ad rem pertinet, quod qui filio suo dari stipulatur, sibi acquirit, quia coniuncta sua persona stipulator efficit, ut non acquirendae obligationis gratia, sed solutionis causa personam filii apprehendisse intelligatur (el que estipula que se le dé a él o a su hijo, comprende la persona de su hijo evidentemente para esto, para que a éste se le pague bien; y no importa que uno estipule para si, o para su hijo; porque se le paga bien al hijo, ya si permanece bajo potestad, ya si fue emancipado; y no hace al caso que el que estipula que se le dé a su hijo adquiere para si, porque habiendo unido su propia persona, hace el estipulante que se entienda que comprendió la persona de su hijo no para adquirir la obligación, sino por causa del pago). 
veía la persona capaz de recibir el pago: tutores, curadores, herederos por las deudas debidas a los pupilos o a la herencia.

En el campo de las obligationes verbis contractae fue frecuente el pago hecho al adiectus solutionis causa y al adstipulator. Fuera de estas personas autorizadas por el acreedor o por el ordenamiento el pago no era válido a no ser que el acreedor autorizase a posteriori la iniciativa del deudor; tampoco era válido y por lo tanto no liberaba al deudor el pago hecho al acreedor aparente o a quien apareciera falsamente legitimado como acreedor, aunque en este caso el deudor podría dirigirse contra el falso acreedor con una actio o condictio indebiti.

Por otra parte, las Instituciones de Justiniano (3, 29 pr.) contemplan que la obligación se extingue por el pago de lo que se debe, o si alguno hubiere pagado, consintiéndolo el acreedor, una cosa por otra. Pero no importa quien pague, si el mismo que debe, u otro por él; pues también se queda libre la deuda pagando otro, ya se haga el pago sabiéndolo o ignorándolo el deudor, o contra su voluntad. Del mismo modo, si hubiere pagado el deudor, quedan también libres los que por él intervinieron. Y lo mismo sucede, por el contrario, si hubiere pagado el fiador; pues no sólo éste queda libre, sino también el deudor (literalmente.: Tollitur autem ovnis obligatio solutione eius, quod debetur, vel si quis consentiente creditote aliud pro alio solveit. Nec tamen interest, quis solvat, utrum ipse, qui debet, an alius pro eo; liberatur enim et alio solvente, sive sciente debitore sive ignorante vel invito solutio fiat. Item si reus solverit, etiam ii, qui pro eo intervenerunt, liberantur. Idem ex contrario contingit, si fideiussor solverit; non enim solus ipse liberatur, sed etiam reus).

\section{Lugar y tiempo}

El pago para efectuar el cumplimiento de la prestación generalmente era fijado por las partes, dado que los juristas entendían por solutio el cumplimiento exacto de la prestación tanto en su contenido como en su lugar y tiempo

Si las partes en el acto constitutivo habían fijado un término, la prestación tenía que entregarse a su vencimiento, o a la verificación de las condiciones si éstas se hubieran impuesto. Si no se había fijado nada sobre ello al constituirse la obligación, la prestación se debía inmediatamente, pero en ciertos casos el tiempo para efectuarse la prestación podía alargarse según las circunstancias de la misma y el 
tipo de prestación ${ }^{80}$. Imaginando que pudiera realizarse el pago en lugar y tiempo oportuno, cumplía el deudor ofreciéndoselo al acreedor. En el caso de no poder o no querer aceptarlo cumpliría el deudor con la prestación dejándolo consignado en lugar público. La fijación de un término puede ser acordada en beneficio del acreedor, del deudor o de ambos. Cuando se fija en beneficio del acreedor éste puede exigir la prestación incluso antes del vencimiento; si se fijó en beneficio del deudor no puede reclamar antes de su vencimiento, pero el deudor tiene la facultad de pagar inmediatamente, y si el acreedor rechaza este pago incurre en mora creditoris.

Según la regla de experiencia que se desprende de la iurisprudentia clásica, solvit ubi petitur, se paga donde se pide, donde se puede reclamar; y está en estrecha relación con el locus solutionis, que a falta de su señalamiento expreso por las partes, en las obligationes in dando se impone que el pago se efectúe (o se reclame en caso de incumplimiento) en el lugar de residencia del deudor que era donde podía ser demandado; en otras ocasiones el locus solutionis dependía de donde se hubiera señalado en el acto constitutivo de la obligación o de las circunstancias de la prestación; de modo que las cosas específicas debían entregarse (y reclamarse) en el lugar donde se encontraban ${ }^{81}$ y las operae libertorum donde se encontrare el patronus, aunque como dice Javoleno ${ }^{82}$ con los gastos y transporte a cargo del patrono.

Reclamar la prestación en lugar distinto de la sedes debitoris podía dar lugar a una plus petitio loco, que aplicando el rigor del procedi-

${ }^{80}$ Pomponio en relación con un supuesto de construcción de un edificio, y citando a Celso (D. 45, 1, 14) estima que el acreedor no podía actuar contra el deudor antes de que hubiese pasado un tiempo razonable para que éste pudiese proceder al cumplimiento (Si ita stipulatus essem abs te: "domum aedificari?» vel heredem deum damnavero insulam aedificare, Celso placet, non ante agi posse ex ea causa, quam tempos praeteriisset, quo insula aedificari posset; nec fideiussores dati ante diem tenebuntur). Otro ejemplo citado por las fuentes es a propósito de las obligaciones de prestar cosas futuras, en las que obviamente había que esperar al tiempo en que estas llegaran a existir; Paulo cita los ejemplos de partos de la esclava, frutos futuros, edificación de una casa, los servicios de un liberto... porque la acción comienza entonces cuando por la naturaleza de las cosas puede darse aquella (D. 45, 1, 73): Interdum pura stipulatio ex re ipsa dilationem capit, veluti si id, quod in utero sit, aut fructus futuros aut domum aedificari stipulatus sit; tunc enim incipit actio, quum ea per rerum naturam praestari potest (...) item si operas a liberto quis stipulatus sit, non ante dies earum cedit, quam indictae fuerint, nec sint praestitae.

${ }^{81}$ D. 5, 1, 38 Licinius Rufinus, lib. 4. Regularum: Quod legatur, siquidem per personalem actionem exigetur, ibi dari debet, ubi est, nisi si dolo malo heredis subductum.

${ }^{82}$ D. 38, 1, 21: Operae enim loco edi debent, ubi patronus moratur, sumtu scilicet et vectura patroni. 
miento formulario dejaba en nada la pretensión del acreedor ${ }^{83}$. Para el pago de créditos de certa pecunia (nacidos de stipulatio, mutuo y legados per damnationem) que estaban tutelados por una actio certi también podía convenirse el pago en lugar distinto del domicilio del deudor.

Las fuentes ponen el ejemplo de stipulatio contraída en Roma de dare pecuniam en Efeso ${ }^{84}$ : el interés del acreedor de cobrar en Éfeso, agravaba la situación del deudor que residía en Roma, por lo que el pretor hizo posible esta reclamación concediendo al acreedor la actio de eo quod certo loco llamada también actio arbitraria ${ }^{85}$, en lugar distinto del de la obligatio in iudicia deducta, teniendo en cuenta el arbitrio judicial el interés de las partes que en la condemnatio impondría una cierta reducción del importe del pago efectuado por el deudor $^{86}$. Esto mismo podía ocurrir con mayor razón en las obligaciones con intentio incerta y especialmente en los iudicia bonae fidei donde el arbitrio judicial era mucho más amplio ${ }^{87}$.

\section{LA CONSIGNATIO EN EL SUPUESTO DE RECHAZO DEL ACREEDOR DEL CUMPLIMIENTO DE LA OBLIGATIO QUE INTENTA LLEVAR ACABO EL DEUDOR. EL PROBLEMA DE LA PRUEBA}

Observemos el siguiente fragmento de Papiniano:

D. 22.1.7Pap., lib. II. Responsorum.

Debitor usurarius creditori pecuniam obtulit, et eam, quum accipere noluisset, obsignavit ac deposuit; ex co die ratio non habebitur usurarum. Quodsi postea conventos, ut solveret, moram fecerit, numi steriles ex eo tempore non erunt.

Se trataba de un deudor, que debía también intereses, y que ofreció al acreedor el importe de la deuda, y no habiéndolo querido reci-

${ }^{83}$ U. Álvarez SuÁrez, Curso de Derecho romano, t. I, Introducción. Cuestiones preliminares. Derecho procesal civil romano, Editorial revista de derecho privado, Madrid, 1955, p. 442 (al hablar de los errores en la Intentio).

${ }^{84}$ Álvarez SuÁrez, op. et loc cit.

${ }^{85}$ D. 13, 4: Alio loco, quam in quem sibi dari quisque stipulatus esst, non videbatur agendi facultas competere; sed quia iniquum erat (...) y en D. 13, 4, 2: Arbitraria actio utriusque utilitatem continet, tam actoris, quam rei. Quodsi rei interest(...).

${ }^{86}$ (...) Quodsi rei interest, minoris fit pecuniae condemnatio, quamintentatum est; at si actoris, maioris pecuniae fiat 528.

87 Álvarez SuÁrez, , Curso de Derecho romano, t. I, Madrid, 1955, pp. 487 y $522-$ 
bir éste, lo selló y lo depositó; desde este día no se tendrá cuenta de los intereses. Pero si demandado después para que pagase, hubiere incurrido en mora, el dinero no será estéril desde este momento.

Este supuesto parece oponerse a la tesis mantenida hasta ahora de que la consignatio tendría efecto liberatorio para el deudor, ya que una vez depositado el importe de la deuda podría sin embargo ser requerido para efectuar el pago por medio de una acción, ya que en realidad no se habría extinguido por ese hecho; lo que está en aparente contradicción con D. 46, 3. 30, Ulpiano, Comentarios al Edicto, libro 51, en donde se dice textualmente: si debitor oferret pecuniam, quae peteretur, creditor nollet accipere, Praetor ei denegat acciones (si el deudor ofreciese el dinero que se le pidiera, y el acreedor no quisiera recibirlo, el pretor le deniega a éste las acciones).

Pese a la duda que se puede plantear, debería afirmarse que el acreedor incurre en mora cuando no acepta el cumplimiento de la obligación por parte del deudor o retarda su cooperación para que el deudor pueda hacer efectivo el pago; dicha cooperación es necesaria cuando el deudor sobre el que pesa la condemnatio y el iudicatum facere oportere después de la litis contestatio ofrece el pago ${ }^{88}$. Se trata de la negativa ante el ofrecimiento de pago.

Esta mora accipiendi produce el efecto de trasladar al acreedor el riesgo por el perecimiento de la cosa, incluso en las obligaciones genéricas ${ }^{89}$ cuando se hubieran individualizado las cosas objeto de la prestación, y siempre que éstas se perdieran sin dolo del deudor. En las obligaciones pecuniarias con pacto de pagar intereses, la mora creditoris produce el efecto de suspender el pago de nuevos intereses desde el momento inicial de la mora ${ }^{90}$ teniendo el acreedor derecho de

${ }^{88}$ Gayo: «Nos queda por ver la conducta seguir por el juez cuando, iniciado el proceso y antes de dictarse sentencia, el demandado da cumplida satisfacción al demandante: si absolverle o antes bien condenarle por cuanto al entablarse el pleito el demandado se encontraba en situación determinante de condena. Los maestros de nuestra escuela consideran que debe ser absuelto, abstracción hecha de la clase de juicio; y de aquí arranca el dicho vulgar de que Sabino y Casio eran de la opinión de que todos los juicios son absolutorios. Los autores de la otra escuela se pronuncian contrariamente en lo que se refiere a los juicios de derecho estricto, mientras que concuerdan en cuanto a los juicios de buena fe, por el libre arbitrio que tiene en ellos el juez. Igualmente opinan en cuanto a las acciones reales, puesto que los términos de las fórmulas así lo expresan (...)». ¿No estamos aquí ante la plasmación por vez primera del principio de la presunción de inocencia que se atribuye la doctrina moderna?

${ }^{89}$ Recuérdese en relación a ellas que la imposibilidad sobrevenida de la prestación no libera al deudor; vid. genus numquam perit.

${ }^{90}$ Cfr. Pap. D. 22, 1, 7: «Un deudor, que debía también intereses, ofreció al acreedor el importe de la deuda, y no habiéndolo querido recibir, lo selló y lo depositó; des 
pretender con una actio utilis $^{91}$ la restitución del dinero depositado. También la mora accipiendi hacía perder al acreedor el derecho de conservar o vender la res pignerata que garantizaba el pago de la obligación principal. En las obligaciones de dare el deudor podía exonerarse de responsabilidad previo ofrecimiento real (oblatio) de la cosa debida consignándola en un lugar público ${ }^{92}$ (depositum in aede publica), como podía ser ante los sacerdotes de un templo (in aedibus sacribus); igualmente desde la mora accipiendi cesaba para el deudor el deber de entregar los frutos de la cosa debida.

En las obligaciones tuteladas por bonae fidei iudicia el deudor ejercitando las acciones contractuales correspondientes podría reclamar al acreedor el resarcimiento del daño (gastos de custodia y conservación de la cosa) producido por su mora; en los iudicia stricti iuris este efecto se produciría en virtud de una exceptio doli (Paulo en D. 45, 1, 73, 2). La responsabilidad del deudor, por tanto, era aligerada notablemente por la mora accipiendi, que cesaba siempre que el acreedor manifestase su voluntad de recibir la prestación debida (Pomponio en D. 18,6,18), aunque también en estos casos el deudor oponiendo una exceptio doli podría ejercitar un ius retentionis para obtener el resarcimiento de los daños producidos por la mora creditoris (Pomponio en D. 33, 6, 8). Pero hay una cuestión que surge a partir de todos las actuaciones descritas, y es el problema que plantea la prueba de que se hayan llevado a cabo ¿Cómo probar que todo se ha realizado conforme a lo previsto?

de este día no se tendrá en cuenta de los intereses. Pero si demandado después para que pagase, hubiere incurrido en mora, el dinero no será estéril desde ese momento»; y C. 4, 32, 19, pr.: Impp. Docletianus et Maximianus AA. et CC. Hyreniae: «Ofrécele al acreedor después de la citación de testigos el capital recibido en mutuo con los intereses lícitos, mas si no lo recibiera, deposítalo consignado en lugar público para que se interrumpa el curso de los intereses legítimos (...)».

${ }^{91}$ C. 4, 32, 19 hasta el final y C. 8, 42, 9: los mismos emperadores a Cassio: «Es evidente que con el depósito de toda la cantidad adeudada hecho solemnemente se verifica la liberación. Pero la oferta de lo adeudado produce la liberación solamente si se hubiere hecho en el lugar en que se debe el pago».

${ }^{92}$ Según TorRent, la voz CONSIGNACIÓN DE LA COSA DEBIDA es un modo de extinguir las obligaciones cuando ofrecido el cumplimiento al acreedor y este se negase a recibirlo, el deudor se liberaba sellando y depositando la cosa debida, Diccionario de Derecho romano, Edisofer, Madrid, 2005. Oblatus, participio de offerre, en la lengua de la Iglesia ha tomado el sentido de ofrecer a Dios, sacrificar, en ERNOUT et MeIllet, Dictionnaire étymologique da la langue latine. Histoire des mots, 4ème edit., Paris, 1967. También BERGER, Encyclopedic dictionary of roman law, Filadelfia, 1953. 


\section{Estudio de algunos medios de prueba del cumplimiento de las obligaciones}

En las obligaciones de dare rem en que el deudor se liberaba realizando el idóneo acto jurídico transmisivo (mancipatio, in iure cessio) este acto era prueba suficiente, y si el acreedor reclamaba la cosa, podía ser repelido por la exceptio doli. En otras clases de obligaciones, en derecho clásico podía probarse el pago por medio de un documento que probablemente sería redactado por los tabularii ${ }^{93}$ (apocha), pero su valor probatorio quedaba a la discrecionalidad judicial tal y como recuerda un fragmento de Ulpiano ${ }^{94}$. Justiniano innovó la materia disponiendo que para los créditos escriturarios, es decir los fijados en documento, la prueba del pago debía igualmente redactarse por escrito en otro documento ${ }^{95}$. Ordenó que la prueba de la solutio se hiciese siempre por escrito en otro documento llamado securi$\operatorname{tas}^{96}$, o bien mediante la confirmación del pago hecha por cinco testigos. En el lenguaje de los rescriptos imperiales securitates es sinónimo de apochae, es decir, los documentos que podían servir de prueba de la exoneración de responsabilidad del deudor para testimoniar la solutio de sus deudas.

De la relevancia otorgada a los documentos redactados por los tabularii ya que sirven de prueba sobre el cumplimiento de las obligaciones que no consisten en un dare, y la discrecionalidad judicial, se

${ }^{93}$ Como señala el prof. D. A. FernándeZ DE Buján, Testigos y documentos en la práctica negocial y judicial romana en RJUAM, n 12,2005 , p. 125 (ó $=R G D R \mathrm{n}^{\circ} 4$, junio 2005, www. iustel. com), los tabularii formaban un cuerpo de esclavos públicos al servicio de la ciudad o la República, que si bien ejercían funciones notariales (notarius, deriva de nota, signo; en lo que aquí interesa haría referencia a personas que ejercían la profesión de copistas, escribientes, que de forma abreviada o taquigráfica recogerían la voluntad de quienes lo requiriesen bien porque no supieran escribir o en el caso de oradores, para que quedase constancia escrita de su discurso en el foro, etc. y MARTínez SARRIÓn, El notario en la baja romanidad, AAMN, XXII, I, pp. 28 ss.), no se llegaba a reconocer a los actos en que intervenían la producción de efectos públicos de la fides pública.

${ }^{94}$ D. 46, 4, 19, 1: Inter acceptilationem et apocham hoc interest, quod acceptilatione omni modo liberatio contingit, liceo pecunia soluta non sit, apocha non alias, quam si pecunia soluta sit. «Entre la aceptilación y la ápoca hay esta diferencia, que por la aceptilación tiene lugar de todos modos la liberación, aunque no se haya pagado el dinero, y con la ápoca no de otra suerte, sino si se hubiera pagado el dinero».

${ }^{95}$ La prueba del cumplimiento de las obligaciones podía hacerse de distintos modos, especialmente por la declaración de testigos, pero desde la época clásica se difundió cada vez más el uso de documentos escritos, recibos escritos por el acreedor en los que declaraba haber recibido el pago. Sobre al prueba en el Bajo Imperio, véase ARCHI, La proba nel Basso Impero, IURA, 12, 1961.

${ }^{96}$ Cfr. C. 4, 20, 18 
desprende asimismo la importancia de los mismos redactores de dichos documentos (apochae). La cuestión que se plantea es la siguiente ¿podrían consignarse dichos documentos en lugar público?

El profesor Fernández de Buján en uno de sus trabajos ${ }^{97}$ sostiene que la actuación de los tabularii se desarrollaba básicamente en el ámbito de la contabilidad, la percepción de impuestos y los archivos públicos, de ahí la consideración de su cargo dentro de los officia publica de las ciudades, no obstante la limitación de sus facultades de autenticadores en relación con la fides publica ${ }^{98}$. En ocasiones, en cuanto escribiente no profesional en cuestiones de técnica jurídica, actuaba el tabularius como testigo cualificado en el testamento del ciego $^{99}$. En otros supuestos se denomina tabularius a la persona ante quien se consigna una cantidad de dinero en el supuesto de venta ${ }^{100}$, y en este último sentido nos interesa tal figura.

Recordemos la exclusividad de los testigos en un primer momento en que los negocios se extinguían por actos formales de sentido contrario; en los negocios per aes et libram la presencia de los testigos era requisito esencial. En época posterior se produjo la decadencia de la exigencia de actos formales de signo contrario, por lo que la consignatio, sería de gran relevancia por sus efectos liberatorios para el deudor ciertamente en determinados casos, por causas taxadas, y si no hubiese otro medio probatorio. Posiblemente requeriría la presencia de los tabularii que deberían hacerlo constar por escrito a efectos probatorios ${ }^{101}$. Pero consignatio sería equivalente a depósito liberatorio para el deudor.

97 A. Fernández de Buján, Testigos y documentos, op. et loc. últimamente cit.

${ }^{98}$ Sobre tabularii, vid. LuZzatTo, Tabularius, en NNDI, XVIII, Torino, 1971, pp. 1012 ss.

${ }^{99} \mathrm{Cfr}$. C 6,22,8 sobre el testamento del ciego.

100 También C 7,72,10,2 tabulariis signare, en relación con la venta de los bienes del deudor: «(...) cuando hay varios acreedores, la parte sobrante una vez cobradas las deudas, lo sellen ellos mismos en presencia de notarios y lo depositen en el tesoro de la santa iglesia de la ciudad en que se celebre el contrato; debiéndose escribir, por supuesto, antes un atestado por los mencionados notarios, estando presente también el que hubiere vendido aquellos bienes o los hubiere transferido a otras personas, de suerte que mediante él se manifieste tanto la cantidad de dinero que se pagó por la venta (...), como la del que se halla sobrante después de pagada la deuda, para que si después apareciera algún acreedor y presentare la garantía de su deuda, pueda satisfacerse a sí mismo con aquella (...)».

${ }^{101}$ Sobre estos temas vid. AmelotTI en sus diferentes obras: , Alle origine del notariato italiano, Roma, 1975, Negocio, documento y notario en la evolución del derecho romano, en AAMN, XIX, 1990, Genesi del documento e prassi negociale, en Scritti Giuridici, Torino, 1996 (=Atti convengo Copanello, 1988, Napoli, 1990), y Testatio, chirographum. Osservazione in tema di tipologia documentali, en Scritti, cit. pp. 130 ss. 
Para designar el escrito de prueba se utilizan diversos términos como instrumentum, documentum, cautio, testatio, quirographum, epistola, scriptura. En lo que aquí interesa, el documento objetivo, testatio, no resulta predominante en la actividad negocial romana hasta fines de la época clásica y su valor probatorio radicaba, ante todo, en los sellos de los siete testigos que junto con el nombre, adscriptio, se hacían constar en la parte interior del documento ${ }^{102}$. Sin embargo, la consignatio no era ni es una actividad negocial, sino un acto jurídico de jurisdicción voluntaria, y además de relevancia, por lo que su existencia posiblemente también requiriese de un documento con valor probatorio, no constitutivo (es decir, independiente del acto realizado) y por tanto de la actividad notarial de los tabellarii.

En relación con el ordenamiento actual, Rafael Gómez-Ferrer ${ }^{103}$, afirmando el origen romano de la expresión jurisdicción voluntaria en base a un texto de Marciano sobre el que ha trabajado extensamente el profesor Fernández de Buján ${ }^{104}$, y a la distinción establecida desde entonces entre jurisdicción contenciosa (llamada así porque se produce cuando hay un conflicto entre litigantes) y voluntaria ${ }^{105}$ (en la que el magistrado interviene sin litigio o conflicto colaborando en la celebración de un acto o negocio jurídico, para cuya celebración se finge la existencia de un proceso $)^{106}$, no puede dejar de observar que «no deben limitarse dichos actos de jurisdicción voluntaria exclusivamente a los judiciales, ya que son numerosos los actos de igual naturaleza atribuidos a otros funcionarios, entre ellos los notarios». Para este autor, existe amplio acuerdo en la doctrina sobre la posibilidad de atribución de actos de jurisdicción voluntaria a notarios, registradores, secretarios judiciales y otros funcionarios, si se considera que la jurisdicción voluntaria no es propiamente jurisdic-

102 Talamanca, Documento y documentazione, en Enciclopedia del Diritto, XIII, 1964, pp. 548 ss. Mientras que en el documento probatorio, el negocio tiene existencia con independencia del documento, en los supuestos de documento constitutivo o dispositivo, el negocio no tiene existencia con independencia del documento, por lo que sólo a partir de su confección se pueden ejercer los derechos derivados de su existencia.

${ }^{103}$ R. Gómez-FERRER SAPIÑa (notario; vicepresidente de la Unión Internacional del Notariado), Visión notarial de la Jurisdicción voluntaria, en Revista jurídica del notariado, abril-junio, 2009, p. 116.

${ }^{104}$ Puede verse, en general, FERnándeZ DE BuJÁN, $D P R, 12^{\mathrm{a}}$ edición, cit., en diferentes epígrafes, sobre todo, p. 390 y ss.

${ }^{105}$ GutiérRez Alviz, Diccionario de iurisprudentia romana.

${ }^{106}$ Verdadero origen de la atribución a los jueces de la jurisdicción voluntaria, en palabras de GómEZ-FERRER SAPIÑA, op. et loc. cit. Véase para profundizar en estas cuestiones, por su importancia, FERNÁNDEZ DE BuJÁN, A., DPR, 12 edición, pp. 390-424. 
ción ${ }^{107}$ salvando así el obstáculo que representaba el artículo 117 apartado 3 de nuestra Constitución española al decir que «reserva el ejercicio de la potestad jurisdiccional exclusivamente a los Juzgados y Tribunales determinados por las leyes, según las normas de competencia y procedimientos que las mismas establezcan». Por el contrario la Exposición de Motivos del «fracasado» Proyecto de Ley de jurisdicción voluntaria de 2007 observa: «La jurisdicción voluntaria encuentra su amparo en el artículo 117. 4 de la Constitución, como función expresamente atribuida a los Juzgados y Tribunales en garantía de derechos que se ha considerado oportuno sustraer de la tutela judicial que otorga el proceso contencioso, claramente amparado en el artículo 117.3 lo que ha permitido atribuir competencias a operadores jurídicos no investidos de potestad jurisdiccional tales como los Secretarios judiciales, los Notarios y los Registradores de la propiedad y mercantiles».

En definitiva, parece afirmar Gómez-Ferrer, que la jurisdicción voluntaria no es jurisdiccional, es decir, no se encuentra comprendida en el artículo 117.3 de la CE, sino en el 117.4: Los juzgados y Tribunales no ejercerán más funciones que las señaladas en el apartado anterior y las que expresamente les sean atribuidas por ley en garantía de cualquier derecho. Es decir comprendería todas aquellas actuaciones que quedan fuera de los límites establecidos por la Constitución.

Siendo así, parece que en la actualidad, sería posible realizar la consignatio ante un notario, y, volviendo a Roma, no sería imposible que se realizara a través de un tabellio ${ }^{108}$. Este escriba de documentos privados ${ }^{109}$ asistiría a los particulares que lo requiriesen en la redacción de documentos, ejerciendo su profesión en el foro o en

${ }^{107}$ Cfr. con el artículo 117. 4 de la C. E. y la Exposición de Motivos del fracasado Proyecto de Ley de jurisdicción voluntaria de 2007: «La jurisdicción voluntaria encuentra su amparo en el artículo 117.4 de la Constitución, como función expresamente atribuida a los Juzgados y Tribunales en garantía de derechos que se ha considerado oportuno sustraer de la tutela judicial que otorga el proceso contencioso, claramente amparado en el artículo 117.3 lo que ha permitido atribuir competencias a operadores jurídicos no investidos de potestad jurisdiccional tales como los Secretarios judiciales, los Notarios y los Registradores de la propiedad y mercantiles».

${ }^{108}$ Sobre la diferencia terminológica y de matices entre tabellarii, tabularii, tabelliones, notarii, vid. FERnÁNDEZ DE BUJÁN, A., DPR, $12^{\mathrm{a}}$ cit., p. 419.

${ }^{109}$ García GaRrido, Diccionario de jurisprudencia romana, cit. y sobre todo AMELotтI, Il documento nel diritto Giustinianeo. Prassi e legislazione, en Il mondo del Diritto nell'epoca giustinianea, Università degli studi di Bologna, Istituto de Antichità Ravennati e Bizantine-Ravenna, 1985, pp. 125-137. 
stationes $\mathrm{u}$ oficinas, estando su labor sometida a ciertas formalidades en época justinianea tal y como se desprende del Codex $x^{110}$ y las Novellae.

\section{El primer documento. Auge de los documentos}

Podemos hacernos dos preguntas. La primera es si hubo documentos relativos a consignaciones; y en caso afirmativo ¿qué valor tuvieron? La segunda, si se da una respuesta afirmativa a la anterior, ¿ante quién se realizarían? ¿sólo ante funcionarios públicos? o ¿valdrían también las actuaciones realizadas y los documentos redactados por tabelliones privados?

Parece ser que el primer documento con valor probatorio, constitutivo (al margen de los ostraca, etc.) del que se tiene constancia es en relación con los actos de última voluntad y en el ámbito del derecho pretorio. Subraya D'Ors ${ }^{111}$ que en los supuestos en los que el pretor prescindiendo de la solemnidad libral, consideró que el testamento eran las mismas tabulae, y ofrecía la bonorum possessio secundum tabulas (sucesión testamentaria del orden pretorio) a quien apareciera instituido en unas tablillas selladas con los sellos íntegros de siete testigos, se podría hablar de un testamento pretorio, escrito, con siete testigos, frente al testamento civil, oral, de cinco testigos, y que en la historia del documento romano, este testamento podría considerarse como el primer documento que aparece con un valor constitutivo, aunque sólo lo fuese a efectos pretorios.

Por otra parte, y en relación con una materia diferente, la regulación constantinea establece la obligatoriedad de la forma escrita en las donaciones relevantes ${ }^{112}$ y en la venta de inmuebles ${ }^{113}$; disposicio-

${ }^{110} \mathrm{C} 4,21,17$, en resumen: los contratos, transacciones, etc., que se convino se hicieran por escrito, no tendrán validez hasta que hayan sido puestos en limpio, y confirmados con las firmas de las partes, y si se escribieran por notario, hasta que también hayan sido completadas por el mismo y al fin hayan sido aprobadas por las partes (Cfr. dicho fragmento directamente ya que no lo reproduzco íntegramente).

${ }^{111}$ A. D’Ors, Derecho Privado romano, $9^{\circ}$ ed., Pamplona, 1997, cit., p. 273.

${ }^{112}$ Fernández de Buján, A., Testigos y documentos, cit., p. 132, citando a AmelotTi en Scritti, cit. p. 128. Las donaciones relevantes requerírían ser documentadas por escrito, la traditio solemne advocata vicinitate, y la allegatio en los gesta municipalia.

${ }^{113}$ La venta de inmuebles o al menos la de fincas rústicas exigía la documentación escrita, la inspectio censualis y la solemne realización del negocio ante vecinos (AMELOTTI, op. cit., p. 129). 
nes que serían atenuadas en sus requisitos por constituciones imperiales posteriores ${ }^{114}$.

Parece ser que por influencia helenística se hizo corriente en Roma la redacción por escrito de todo tipo de actos negociales; esta preponderancia de la escritura llevó incluso a considerar que la propiedad se transmitía al adquirente con la entrega de la documentación relativa sin necesidad de ningún acto material de entrega por parte del tradens ni de toma de posesión material por el accipiens ${ }^{115}$. Las disposiciones de Constantino, enmarcadas en la exigencia de la certeza del derecho, propia de la era postclásica, supondrían el nacimiento del instrumentum publicum ${ }^{116}$. El documento en dicha época, en ocasiones daría por realizada la transferencia, la entrega de la cosa, aunque no se hubiese realizado, ni se fuese a realizar en el futuro $^{117}$.

Junto al documento constitutivo, parece que se produjo también es esa época, una sustitución de las tabulae ceratae por papiros y pergaminos, así como una prevalencia absoluta de los quirographa griegos como forma documental ${ }^{118}$. La desaparición en esta etapa de la figura del jurista (del jurista cautelar republicano y del jurista clásico) junto con la ausencia de un cuerpo de expertos en la redacción técnica de escrituras jurídicas (que no había llegado a llenar la actividad de los notarii al desconocer éstos, en general, el funcionamiento de las instituciones jurídicas), supuso el auge del documento (al que el jurista clásico había prestado poca atención por considerar tan solo su valor como prueba en juicio) y de la clase profesional de los tabelliones, como expertos profesionales en la técnica documental

${ }^{114}$ Por ejemplo, al concretarse el importe de la venta en 200, 300 o 500 monedas de oro, solidi, así como en relación con las donaciones entre cónyuges y entre padres e hijos, o los testamentos solemnes (FERNÁNDEZ DE BuJÁn, A., op. cit., p. 133 con citas del Codex Justinianeo en nota a pie 69)

115 Torrent, voz Traditio en Diccionario de Derecho romano, cit, p. 1369.

${ }^{116}$ Amelotti, Il documento cit., p.128 y Sola RIED, Valor de los documentos relativos a transferencias en tiempos de Diocleciano, en Anuario de la Facultad de Derecho, La Coruña, 4, 2000, pp. 535 ss. El documento en época postclásica, en ocasiones da por realizada la transferencia, la entrega de la cosa, aunque no se haya realizado, ni se vaya a realizar en el futuro. Sobre la prueba en general, ARCHI, La proba nel diritto del Basso Impero, en IURA, 12, 1961, ya citado.

${ }^{117}$ Se trata de la traditio per chartam de origen oriental; su presencia en los ordenamientos actuales puede cfr. leyendo el artículo 1462 del Código civil para la compra-venta.

${ }^{118}$ Chirographum, documento escrito que originariamente era un medio de creación de relaciones obligatorias importado a Roma desde el mundo helenístico; literalmente significa escrito a mano (TORRENT, Diccionario de Derecho romano, cit.) 
y en la materia jurídica, que, a cambio de honorarios, ponían sus conocimientos al servicio de los particulares que lo requerían ${ }^{119}$.

\section{La figura de los tabelliones}

Se ha dicho más arriba que se trataba de un escriba de documentos privados ${ }^{120}$ que asistiría a los particulares que lo requiriesen en la redacción de documentos, desempeñando su profesión en el foro (de ahí el término práctica forense) en una especie de oficinas llamadas stationes.

En el texto que sigue a continuación aparece por primera vez la mención de los tabelliones. Dedicado el título a las penas, y en relación a aquellas que consisten en la prohibición de algún acto, Ulpiano, en D. 48, 19, 9, 4, observa que:

Nonnumquam non advocationibus cui interdicitur, sed foro. Plus est autem foro quam advocationibus interdicere. Si quidem huic omnino forensibus negotiis accomodare se non permittatur. Solet autem ita vel iuris studiosis interdici, vel advocatis, vel tabellionibus sive pragmaticis. 5. Solet et ita interdici: ne instrumenta omnino forment, neve libellos concipiant, vel testaciones consignent. 6. Solent et sic: Ne eo loci sedeant quo in publico instrumenta deponuntur, archivo forte vel grammatophilacio.

Ulpiano realiza una nítida separación entre profesiones jurídicas al distinguir entre iuris studiosi, advocatis, tabelliones y pragmatici. Hace también mención de las funciones que como profesionales desarrollan los tabelliones: redactar documentos (instrumenta formare), escribir instancias (libellos concipere), sellar testimonios (testationes consignare) y otorgar testamentos, escribirlos o sellarlos (testamenta ordinare, vel scribere, vel signare). Asimismo señala los lugares públicos en los que el tabellio, al igual que sus antecesores griegos ejercen su actividad: en el foro y en los archivos públicos (de ahí también el que en disposiciones posteriores se les denominase forenses) ${ }^{121}$. Ciertamente sellar testimonios equivale a consignare en el sentido amplio del término. No se alude a la figura de la consignatio como mecanismo de liberación del deudor. Es decir, no aparece expresamente re-

${ }^{119}$ Fernández de Buján, A., Testigos y documentos, cit., p. 133.

${ }^{120}$ GARCía GARRIDO, Diccionario de jurisprudencia romana, cit.

${ }^{121}$ Según Fernández de Buján, A., op. et loc. cit. y el mismo Autor en su DPR, $12^{\circ}$ edición, pp. 519 ss. 
flejado que ésa fuese una de las tareas del tabellio. Pero cabe plantear dicha posibilidad y de ahí derivaría la acepción de consignación en la denominación actual.

La tardanza en aparecer esta profesión, tabelliones, (Ulpiano escribe en el $215 \mathrm{dC}$ ) si se compara con la importancia que cumplía en Grecia la función pública, debe ponerse en relación con el carácter verbal de la primitiva negociación que tenía en el testamentum, la mancipatio y la stipulatio sus principales referencias ${ }^{122}$. No dejan de ser en ningún momento desde su aparición en época clásica profesionales privados; bien es verdad que en el Imperio absoluto fueron sometidos a un estricto control y subordinación al poder político, de acuerdo con la burocratización de la época, lo que les llevó a ser tenidos como funcionarios públicos en diversos aspectos tales como considerar documento público al escrito por ellos redactado, y dotarlo de fuerza probatoria en juicio. Sin embargo no se les atribuye a dichos documentos plena fides publica, ya que el ius actorum conficiendorum fue competencia exclusiva de los funcionarios públicos ${ }^{123}$ y ellos no lo eran.

En sus orígenes, el documento tabeliónico se enmarca en cuanto a su regulación y en cuanto a sus efectos, más en la órbita del documento privado que en la del documento público en una evolución lenta y llena de cautelas, sobre todo en relación con el instrumentum publice confectum que no deja de producirse hasta la etapa final de la legislación justinianea ${ }^{124}$.

En la etapa postclásica son varias las constituciones imperiales que no distinguen a efectos probatorios entre documento privado y documento tabelliónico, o equiparan los testigos al tabellio a estos efectos $^{125}$, y en la etapa final de la evolución sobre la fuerza probato-

122 Fernández de Buján, A., Testigos y documentos. cit., p. 134, nota 74 a pie. En este sentido, el testamentum calatiis comitiis, por ejemplo testimoniaría la voluntad del pater familias. En los negocios per aes et libram, no debería haber existido seguramente ninguna dificultad probatoria.

${ }^{123}$ En virtud del ius conficiendorum se otorgaba a los titulares de este derecho la facultad de confeccionar y autorizar actas y expedientes en los que se reflejaban las actuaciones y procedimientos que tenían lugar en su presencia. Una copia de tales expedientes, que tenía el carácter de documento público, se entregaba a los interesados. Tales documentos gozaban de pleno valor probatorio, fides publica, respecto de todas las autoridades del Estado y, por tanto ante los Tribunales de Justicia (FERNÁNDEZ DE Buján, op. cit., p. 136). Sobre documento público, vid. Talamanca, Documento y Documentazione, en Enciclopedia del Diritto, XIII, 1964, pp. 548-552.

${ }^{124}$ FernándeZ de Buján, A., op. cit., p. 137.

${ }^{125}$ Varias constituciones del emperador Zenón (año 486) C.4,20,15,1 y C.4,21,16,1. 
ria de los documentos en juicio, los documentos privados no daban fe más que cuando eran reconocidos como verdaderos por la persona contra la cual se oponían o por el juez, en cuyo caso probaban lo mismo que un documento público. La prueba ante el juez de un documento privado que no había sido reconocido, cabría hacerla o por la comparatio litterarum, o por juramento decisorio o por testigos. Más valor tendrían los instrumenta quasi publice confecta, cuya fuerza probatoria derivaría de la buena reputación de los tres testigos suscriptores. Mayor importancia se daría a los documentos tabeliónicos o instrumenta publice confecta que precisaban para producir plena fides pública ser corroborados por la prueba testifical o la verificación de escritura, o la insinuación o depósito de tales documentos en los Archivos públicos, o el testimonio del tabellio que hubiera confeccionado el documento ${ }^{126}$. Estos actos podrían ser catalogados como quasi iudicia figura, es decir, no contenciosos, por lo tanto dentro de la categoría de actuaciones de jurisdicción voluntaria ${ }^{127}$. Como último hito de la evolución en cuanto a la fuerza probatoria de los documentos en los procesos civiles, se establece en la Novela 73, capítulo VII, que la credibilidad del documento notarial puede basarse en el testimonio juramentado del tabelio, al que ha de añadirse el del escribiente, en su caso, del documento y el del contador, pero se añade «si no se tomó contador, y el mismo notario escribió todo el documento y lo perfeccionó, o también si no está presente el que lo escribió, o por otra causa no puede él comparecer, atestigüe el notario bajo juramento su propia intervención, de suerte que no haya lugar al cotejo y sean así fidedignos los documentos...» ${ }^{128}$.

En fin, todo lo anterior podría servir para explicar la importancia del documento a la hora de demostrar que había sido depositada una suma como prestación debida en una obligatio en la que no se quiso o no se pudo aceptar el pago (solutio) como extinción de dicha obligación. Es posible imaginar que aquel que la hiciera quisiera tener una prueba fehaciente de su acto, para que éste tuviera los efectos extintivos o liberatorios de la obligación contraída. Por ello no resultaría extraño que lo hiciera acompañar de un documento aunque hubiese sido redactado por un profesional privado (tabellio). Tendría

${ }^{126}$ FernándeZ DE Buján, A., op. cit., p. 138. En este sentido una constitución de Justiniano del 530 (C. 4,21,20) dispone que si en los instrumenta publice confecta, los tres testigos suscribientes no estuvieren presentes, excepcionalmente bastará el testimonio juramentado del tabellio para probar la autenticidad del documento. También en $D P R, 12$ edición, p. 420.

${ }^{127}$ FERnÁNDEZ DE BuJÁN, A., DPR, 12 a , cit., p. 421.

${ }^{128}$ FERNÁNDEZ DE BuJÁN, A., DPR, 12 ${ }^{\mathrm{a}}$, cit., p. 521. 
verdadera fuerza probatoria, y ello a pesar de que el único documento que probaba por sí mismo su autenticidad era el documento público $^{129}$. Por otra parte puede afirmarse con Amelotti que desde la época postclásica no fueron ya los tabelliones profesionales privados strictu sensu, aunque tampoco llegaron a ser considerados como funcionarios públicos en sentido técnico ${ }^{130}$. Además señala el profesor Fernández de Buján ${ }^{131}$, que la actuación de los tabularii se desarrollaba sobre todo en el ámbito de la contabilidad, la percepción de impuestos y los archivos públicos, por lo que se consideraba su cargo dentro de los officia publica de las ciudades a pesar de la limitación de sus facultades de autenticadores en relación con la fides publica ${ }^{132}$. Otras veces actuaba el tabularius como testigo cualificado ${ }^{133}$. Pero también se denominaba tabularius a la persona ante quien se consignaba una cantidad de dinero en el supuesto de venta ${ }^{134}$, por lo que hay datos en las fuentes que acreditan la consignatio como medio de desligar al deudor de su obligatio.

Otro supuesto recogido en el Codex es el que hace referencia a la consignación de la cantidad sobrante de la venta de los bienes del deudor, una vez cobradas las deudas y siendo varios los acreedores: «La parte sobrante debe ser sellada ante el notario y depositada ante el tesoro de la iglesia de la ciudad donde se haya celebrado el contrato, debiéndose escribir antes un atestado por los notarios en presencia del vendedor y así constará tanto la cantidad que se pagó por la venta como la cantidad sobrante por si luego apareciera otro acreedor que deba ser satisfecho» ${ }^{135}$.

${ }^{129}$ Los documentos públicos tienen una fuerza probatoria plena, por lo que eran inatacables en juicio, Autor, op. et loc. cit. anteriormente, p. 522.

130 Amelotti, Il documento cit. p. 128, cit. por Fernández de Buján, A., Testigos y documentos, op. cit., p. 142.

${ }^{131}$ FERnÁNDEZ DE BujÁN, A., Testigos y documentos op. et loc. últimamente cit.

132 Remito a LuzzatTo, Tabularius, en NNDI, cit., pp. 1012 ss.

${ }_{133}$ Cfr. C. 6, 22, 8 recuérdese, sobre el testamento del ciego.

${ }^{134}$ Se trata de C. $7,72,10,2$; tabulariis signare, en relación con la venta de los bienes del deudor: (...) cuando hay varios acreedores, la parte sobrante una vez cobradas las deudas, lo sellen ellos mismos en presencia de notarios y lo depositen en el tesoro de la santa iglesia de la ciudad en que se celebre el contrato; debiéndose escribir, por supuesto, antes un atestado por los mencionados notarios, estando presente también el que hubiere vendido aquellos bienes o los hubiere transferido a otras personas, de suerte que mediante él se manifieste tanto la cantidad de dinero que se pagó por la venta (...), como la del que se halla sobrante después de pagada la deuda, para que si después apareciera algún acreedor y presentare la garantía de su deuda, pueda satisfacerse a sí mismo con aquella (...).

${ }^{135}$ Véase directamente: C. 7, 72, 10, 2. 


\section{LA CONSIGNATIO EN CASO DE MINORÍA DE EDAD DEL ACREEDOR ¿SE DESLIGA DE SU OBLIGACIÓN DE SOLVERE EL QUE CONSIGNA EN VEZ DE PAGAR AL MENOR O A SU TUTOR?}

En Derecho romano parece poder afirmarse con base en algunos supuestos recogidos en las fuentes ${ }^{136}$, que por este «mecanismo» ${ }^{137}$, el obligado se desliga de la obligación que contrajo. Podrían servir de apoyo para la consideración de esta tesis la lectura de los mismos.Veamos:

\section{22. 1. 1. 3 Papinianus, lib. II. Quaestionum:}

Circa tutelae restitutionem pro favore pupillorum latior interpretatio facta est; nemo enim ambigit hodie, sive iudex accipiatur in diem sententiae, sive sine iudice tutela restituatur, in eum diem, quo restituit, usuras praestari. Plane si tutelae iudicio nolentem experiri tutor ultra convenerit, et pecuniam obtulerit, eamque obsignatam deposuerit, ex eo tempore non praestabit usuras.

El caso que se presenta trata de un supuesto de tutela y dice así:

En cuanto a la restitución de la tutela se hizo una interpretación más lata a favor de los pupilos; porque nadie duda hoy, que se pagan en intereses hasta el día de la sentencia, si se acudiera al juez, o hasta el día en que uno la restituye, si la tutela fuera restituida sin la intervención del juez. Pero a la verdad, si voluntariamente hubiere demandado el tutor al que no quisiera ejercitar la acción de tutela, y le hubiere ofrecido el dinero, y lo hubiere depositado sellado, no pagará intereses desde ese tiempo.

\section{26.7.28.1 Marcellus, lib. VIII, Digestorum.}

Tutor, qui post pubertatem pupillo negotiorum eius administratione abstinuit, usuras praestaret non debet, ex quo obtulit pecuniam. Quin etiam iustius mihi videtur, eum, per quem non stetit, quominus conventus restitueret tutelam, ad praestationem usurarum non compelli. Ulpianus notat: non sufficit obtulisse, nisi et deposuit obsignatam tuto in loco.

${ }^{136}$ Las fuentes referidas por García Garrido en su Diccionario de Jurisprudencia romana, voz consignatio, son las siguientes:

D. 22. 1. 1. 3; D. 22. 1. 7; D. 26. 7. 28. 1. En concreto para el caso de pago deferido al menor por parte del tutor, véase el primero de ellos. Y creemos que análogamente se podría considerar la liberación por parte del deudor cuyo acreedor fuera menor, consignando el importe de la deuda, ya que esos actos, los que benefician al menor, no necesitan de la auctoritas interpositio por parte del tutor.

${ }^{137}$ Utilizando la terminología empleada por CANO HURTADO a lo largo de toda su obra, La consignación como mecanismo de liberación del deudor, Madrid, 2005, cit. 
El tutor, que después de la pubertad del pupilo se abstuvo de la administración de los negocios de éste, no debe pagar intereses desde que ofreció el dinero. Antes bien, me parece más justo, que aquel en quien no consistió que habiendo sido demandado, no restituyese la tutela, no sea compelido a la prestación de intereses. Ulpiano observa: No basta que lo haya ofrecido, si también no lo depositó sellado en lugar seguro.

\section{LA CONSIGNATIO POR AUSENCIA DEL ACREEDOR, O DESCONOCIMIENTO DE SU PERSONA, O POR DEFECTO EN LA AUTORIZACIÓN AL REPRESENTANTE DEL ACREEDOR, ¿LIBERA AL DEUDOR?}

Si consideramos que la consignatio de la cosa debida, es un acto de jurisdicción voluntaria que tiene como efecto la liberación del deudor ante la negativa del acreedor a recibir el pago, no es imposible considerar que también tendría el mismo efecto cuando no pudiera realizarse dicho pago por no conocer el paradero del acreedor, o incluso por no conocer la persona del acreedor; o incluso cuando existiendo un representante del mismo, hubiese un defecto en dicha autorización. Todo ello nos hace entrar de lleno en el tema de la representación en Roma y de la ineficacia de los actos jurídicos en algunos supuestos. Vayamos por partes.

\section{La consignatio en caso de ausencia del acreedor}

En los Fragmentos Vaticanos ${ }^{138}$, se observan una serie de consideraciones a propósito de los representante procesales y los procuradores, que bien podrían aplicarse a la persona del representante del acreedor o a la persona que actúa como gestor de los negocios ajenos, y ello a sabiendas de la dificultad que entraña la aplicación de la teoría de la representación directa e inmediata en Roma al menos hasta la última etapa de la evolución del derecho romano, en época bizantina. La representación directa sólo de modo precario y excepcional fue admitida en Derecho romano; y ello, a través de soluciones prácticas introducidas por obra del pretor y la jurispru-

${ }^{138}$ FV en las páginas 145 y 147 punto 338 de la versión de Amelia CASTRESANA, que sigue básicamente el texto latino de la edición anotada de Baviera (FIRA, pars altera, Auctores, Florencia, 1940), así como el texto recogido por GIRARD-SENN en sus Textes de Droit Romain, Dalloz, $7^{\text {a }}$ edición, Paris, 1967; cfr. directamente en FIRA cit. 
dencia $^{139}$. Si bien no implica representación la posibilidad de que en un negocio jurídico se estipule que el deudor pueda pagar válidamente a un tercero, que aparece así como facultado para recibir el pago (no para exigirlo), por lo que se le designa con el nombre de adiectus solutionis gratia ${ }^{140}$. Son ilustrativos al respecto los textos de Gayo, Marciano y Paulo que se trancriben a continuación:

Gayo, en D. 45, 1, 141, 3 De las obligaciones verbales: Si ita fuero stipulatus: "mihi aut Titio»et tu mihi daturum te spondeas, secundum omnium opiniones ad interrogatum te respondere, quia constant, mihi soli acquiri obligationem; Titio autem duntaxat recte solvitur

si yo hubiera estipulado así: «a mí o a Ticio», y tú prometieras que me darás a mí, respondes, según la opinión de todos, a lo que se interrogó, porque es sabido que se adquiere para mí solo la obligación; pero se le paga bien solamente a Ticio.

Idem, 8: Ex hoc apparet, si diversa conditio in meam personam, diversa in Titii posita sit, nec in meam personam extiterit conditio, totam stipulationem nullius momenti futuram; extante vero mea conditione, si quidem Titii quoque conditio extiterit, poterit vel Titio solvi; si vero in illius persona defecerit, quasi non adiectus habebitur

de esto aparece, que si se hubiera puesto una condición respecto a mi persona, y otra diversa en cuanto a la de Ticio, y la condición no se hubiese cumplido respecto a mi persona, habrá de ser de ningún valor toda la estipulación; pero cumpliéndose mi condición, si verdaderamente se cumpliere también la condición de Ticio, se podrá pagar aun a Ticio; pero si hubiere faltado en cuanto a la persona de éste, éste se tendrá como no agregado.

Idem 9: Ex his ómnibus apparet, liceo alterius persona non recte adiiciatur, non ideo minus in nostra persona utiliter procedere stipulationem

resulta de todo esto, que aunque no sea convenientemente agregada la persona de otro, no por esto procede menos útilmente la estipulación en cuanto a nuestra persona.

Gayo en D. 45, 3, 28, pr.: Si ex re domini domino aut fructuario servus stipulatus fuerit, domino quidem acquiri obligationem Iulianus scripsit; solvi autem fructuario posse, quasi quolibet adiecto

139 Álvarez SuÁrez, U., El negocio jurídico en Derecho Romano, Madrid, 1954, p. 97. Para un estudio más amplio sobre la representación, véanse las páginas $84-98$ de la misma obra.

${ }^{140} \mathrm{Vid}$. en este sentido, por ejemplo, el fragmento de Gayo en relación a las obligaciones verbales, recogido en D. 45, 1, 141, 3, 8 y 9 y D. 45, 3, 28, pr.; también el de Marciano en D. 46, 1, 23 y los de Paulo en D. 46, 3, 98 y D. 46, 3, 59. 
si respecto a cosa de su señor hubiere un esclavo estipulado para su señor o para el usufructuario, escribe Juliano que la obligación se adquiere ciertamente para el señor; mas se le puede pagar al usufructuario, como a otro cualquiera adjunto.

Marciano en D. 46, 1, 23 Reglas lib. IV: Si mihi aut Titio decem stipulatus fuerim, Titius fideiussorem accipere non potest, quia solutionis tantum causa adiectus est

si yo hubiere estipulado diez para mí o para Ticio,Ticio no puede recibir fiador, porque fue agregado solamente por causa del pago.

Paulo en D. 46, 3, 59 Comentarios a Plaucio lib. II: Si ita stipulatus sim. "mihi aut Titio dare spondes?" et debitor constituerit se mihi soluturum, quamvis mihi competat de constituta actio, potest ad huc adiectio solvere (...)

si yo hubiere estipulado así: «¿prometes darme, o a Ticio?» y el deudor hubiere determinado que me pagará, aunque me competa la acción por el dinero constituido, puede todavía pagarle al adjunto (...).

Puede suceder que, ajustándose a lo convenido, el deudor ofrezca pagar al acreedor, y éste, sin justa causa, rehúse aceptarlo, como ya se ha visto; pero también pudiera suceder que pretendiendo el deudor verificar el pago, no le fuese posible realizarlo por encontrarse ausente el acreedor. En el primer supuesto, hecha la oferta real de pago, y en el segundo, directamente, el deudor podría proceder a consignar la cosa debida en un lugar público en cuyo caso el deudor quedaría liberado ipso iure tal cual si hubiere efectuado genuino pago. En este sentido puede verse el fragmento de la constitución dada por Diocleciano y Maximiano a Hirenia, recogida en el título De los intereses en C. 4, 32, 19:

Acceptam mutuo sortem cum usuris licitis creditori post testationem offer: ac si non suscipiat consignatam in publico depone, ut cursus legitimarum usurarum inhibeatur. In hoc autem casu publicum intellegi oportet vel sacratísimas Aedes, vel ubi competens iudex super ea re aditus deponi eas disposuerit. Quo subsecuto etiam periculo debitor liberabitur (liberaberis), et ius pignorum tollitur, cum Serviana etiam actio manifeste declaret, pignoris inhibere persecutionem vel solutis pecuniis vel si per creditorem steterit,quominus solvatur. Quod etiam in traiecticiis servari oportet. Creditori scilicet actione utili ad exactionem earum non adversus debitorem, nisi forte eas, receperit, sed vel contra depositarium vel ipsas competente pecunias

El capital recibido en mutuo, con los intereses lícitos, ofrecérselos, previa invocación de testigos, al acreedor; pero si no lo recibiera, 
deposítelo consignado en lugar público, a fin de que se interrumpa el curso de los intereses legítimos. En este caso se debe entender por lugar público, a los sacratísimos edificios (imperiales), o el sitio donde el juez competente a quien se haya recurrido hubiere dispuesto que se depositen. Hecho lo cual, el deudor quedará también exento del riesgo, y se extingue el derecho del pignus; ya que también la acción Serviana declara terminantemente que se extingue la persecución de la prenda, bien pagándose el dinero, bien si hubiese consistido en el acreedor el que no se pagase; lo que también debe observarse en los préstamos marítimos; compitiéndole, por supuesto, al acreedor la actio utilis para la exacción de estas cantidades, no contra el deudor, a no ser que casualmente las hubiera recibido de nuevo, sino contra el depositario o contra el dinero mismo.

Hay que señalar, que también se puede hablar de consignación de la cosa dada en custodia (en el contrato de depósito) cuyo fundamento real es la obligación de restituir por parte del depositario ${ }^{141}$. Y por sorprendente que pudiera parecer, no es necesario que el depositante fuera propietario: también el ladrón puede convertirse en acreedor por haber depositado el objeto robado. Para Bonfante el depositario debe custodiar el objeto y no usarlo ${ }^{142}$, de lo contrario cometería furtum usus; no se cuestiona la titularidad del depositante. El deudor, que es el depositario, se desliga de su obligatio, que consiste en un dare, por medio del mecanismo de la consignatio.

Un supuesto muy interesante es el recogido por Quintana Orive, en uno de sus trabajos ${ }^{143}$; se trata a propósito de D.16. 3. 1. 37. En este fragmento, Ulpiano refiere el pensamiento de Juliano en caso de no saber con certeza la persona del acreedor en un supuesto particular. Se trataba de lo siguiente: a la muerte del acreedor depositante de un objeto determinado, sus herederos que eran varios, afirmando cada uno ser el único heredero, reclamaron al depositario la restitución de la cosa ¿a quién debería devolver el depositario la cosa para quedar liberado de la obligación asumida en el contrato de depósito?

${ }^{141}$ Véase ampliamente, García VÁzouez, C., Extinción de la responsabilidad por depósito o consignación de cosa debida, en La responsabilidad civil. De Roma al derecho moderno, Actas del IV Congreso Internacional y VII Congreso iberoamericano de Derecho romano, Burgos, 2001, pp. 415-428.

${ }_{142}$ Bonfante, Istituzioni di Diritto romano, Giuffrè edit., Milano, 1987, p. 387.

143 Quintana Orive, E., «Observaciones sobre el depósito de la cosa debida en caso de mora creditori» RIDA, $3^{\mathrm{a}}$ serie, tomo 46, 1999, pp. 427-450, con casuística abundante examinada por la Autora. 
Apud Iulianum libro tertio decimo Digestorum talis species relata est; ait enim, depositor decesserit, et duo existant, qui inter se contendant, unusquisque solum se heredens dicens, ei tradendam rem, qui paratus est, adversus alterum reum defendere, hoc est, eum, qui depositum suscepit; quodsi neuter hoc onus suspiciat. Commodissime dici ait, non esse cogendum a Praetore iudicium suscipere; oportere igitur rem deponi in aede aliqua, donec de hereditate indicetur.

La solución aportada por Juliano es la siguiente: La cosa deberá ser consignada a quien diese caución de defendere adversus alterum reum; es decir, a aquél de los contendientes que estuviese dispuesto a defender al depositario frente a la reclamación del otro heredero. Por tanto (igitur), en caso de que ninguno lo hiciera (hoc onus suscipiat), el depositario (deudor) debería depositar la cosa en un templo hasta que el magistrado se pronunciase sobre la contienda hereditaria, considerando por tanto, que dicho depósito tendría efecto liberatorio para el depositario (deudor).

\section{PRIMERAS CONCLUSIONES}

En época antigua no existió la consignatio como mecanismo de liberación del deudor y sí tan solo, la posibilidad de abandonar la cosa ante la mora del acreedor.

En época clásica surge la posibilidad de consignatio en lugar público con efectos liberatorios para el deudor. Ya no se faculta al deudor a abandonar la cosa y la consignatio debe hacerse en lugar público debiendo realizarse la oblatio (oferta de pago), obsignatio (acto de sellar o guardar las cosas) y depositio (depósito) para poder hablar de ella. Ninguno de estos actos por separado extingue la obligación del deudor.

Se trata de un acto de los llamados de jurisdicción voluntaria, pues la oposición a la misma daría lugar a una controversia que abriría paso a un juicio contencioso.

En época postclásica se admite la posibilidad de admitir como prueba en juicio los documentos redactados por tabelliones, que en el proceso civil seguramente producirían como efecto la liberación del deudor ya que en ellos aparecería reflejada la consignación de la cosa debida, aunque únicamente para los supuestos recogidos en las fuentes; parece que el pago por consignación sería procedente tan sólo en las deudas de dinero o cosas muebles ${ }^{144}$ ante la dificultad o

${ }^{144}$ En las obligaciones de dare. 
imposibilidad que entrañaría el depósito de bienes inmuebles; por otra parte, aunque extinguiría plenamente la deuda con todos sus accesorios, el deudor podría retirar las cosas consignadas antes de que el acreedor las hubiere tomado, en cuyo caso la obligación renacería en toda su amplitud ${ }^{145}$. Sin embargo hay que matizar, cómo para obligaciones que no consistieran en un dare, podría realizarse a través de un documento tabelliónico que constituiría un modo de prueba suficientemente fuerte para desligar al deudor de su obligatio, en un proceso civil, aunque es dudoso que estos supuestos pudieran considerarse dentro de lo que hemos denominado, consignación.

${ }^{145}$ CRIstóbal Montes, Curso de Derecho romano. Derecho de obligaciones, UCV, $2^{\mathrm{a}}$ ed. Caracas, 1999, p. 709. 